\title{
"Mingled in One Common Destruction": Gender and the Household Economy in Harpers Ferry, 1859-1865
}

\author{
Elizabeth Conant-Lambert
}

Follow this and additional works at: https://researchrepository.wvu.edu/etd

\section{Recommended Citation}

Conant-Lambert, Elizabeth, "'Mingled in One Common Destruction": Gender and the Household Economy in Harpers Ferry, 1859-1865" (2017). Graduate Theses, Dissertations, and Problem Reports. 5384. https://researchrepository.wvu.edu/etd/5384

This Thesis is protected by copyright and/or related rights. It has been brought to you by the The Research Repository @ WVU with permission from the rights-holder(s). You are free to use this Thesis in any way that is permitted by the copyright and related rights legislation that applies to your use. For other uses you must obtain permission from the rights-holder(s) directly, unless additional rights are indicated by a Creative Commons license in the record and/ or on the work itself. This Thesis has been accepted for inclusion in WVU Graduate Theses, Dissertations, and Problem Reports collection by an authorized administrator of The Research Repository @ WVU. For more information, please contact researchrepository@mail.wvu.edu. 


\title{
"Mingled in One Common Destruction": \\ Gender and the Household Economy in Harpers Ferry, 1859-1865
}

\author{
Elizabeth Conant-Lambert
}

\author{
Thesis submitted \\ to the Eberly College of Arts and Sciences \\ at West Virginia University \\ in partial fulfillment of the requirements for the degree of \\ Master of Arts in History
}

Brian Luskey, Ph.D., Chair

Jason Phillips, Ph.D.

Kimberly Welch, Ph.D.

Department of History

Morgantown, West Virginia

2017

Keywords: gender, household economy, American Civil War, Harpers Ferry

Copyright 2017 Elizabeth Conant-Lambert 


\begin{abstract}
"Mingled in One Common Destruction":

Gender and the Household Economy in Harpers Ferry, 1859-1865

Elizabeth Conant-Lambert

This thesis examines gender relations and the household economy of Harpers Ferry, Virginia (later West Virginia) from 1859 to 1865 . Chapter One looks at how the town was organized economically and symbolically around the federal armory and arsenal, which served as the foundation for the town. Chapter Two examines the destruction of the armory and the ways that economic upheaval led to a feminization of male townspeople, who were then subordinated to occupying militaries. In the border town of Harpers Ferry, occupation became an important aspect of gender relations. Chapter Three focuses on how local women used family networks to choose their own status as household dependents and reoriented the economy around the presence of soldiers. Throughout this thesis, townspeople are analyzed as key participants in the events of John Brown's raid and the Civil War. They used ideas about gender to shape their occupation and relationship with soldiers to survive when the town's economy was destroyed.
\end{abstract}




\section{Acknowledgements}

First, I would like to thank my thesis committee for their insights and questions that helped to shape and reshape this project. Dr. Brian Luskey has been particularly kind in enthusiastically stepping in and guiding the project. His optimism about this thesis was most supportive.

I would also like to thank the staffs at Harpers Ferry National Historical Park. Duke University's David M. Rubenstein Rare Books and Manuscripts Library, Jefferson County Museum, and the West Virginia Regional History Center for all their assistance.

I never would have started this project without the enthusiasm of the park rangers in the Living History Branch at Harpers Ferry National Historical Park. John King and Melinda Day always show enthusiasm in mentoring young employees and in sharing their knowledge with thousands of visitors over the years. It was my honor to work alongside both of them and to work inside the buildings which I describe in this thesis. John and Melinda helped to inspire my love of Harpers Ferry. I thank you for their confidence in me and for all the lessons they taught me over the years.

Finally, I thank my family and my husband for being ever hopeful and supportive. 


\section{Table of Contents}

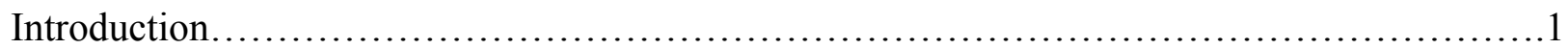

Chapter One: The Gun-Making Household.......................................... 10

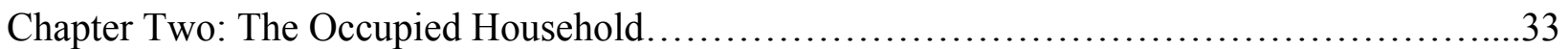

Chapter Three: The Reconstituted Household..........................................59

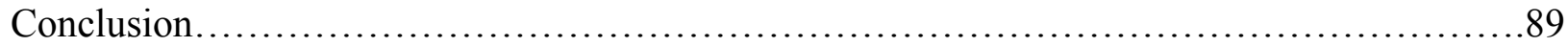

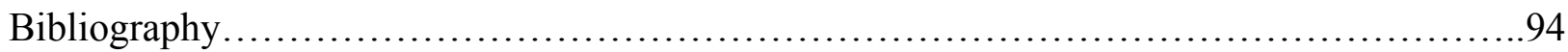




\section{Introduction}

When modern-day visitors enter the town of Harpers Ferry, they experience a strange juxtaposition of destruction and natural beauty. The relics of eras past stand side by side, and the history and stories of the place blend together. John Brown's fort still stands but not at the original location and the layout of the building was reversed when relocated. It stands just below the destroyed downtown section of the town called the Point. From this location, it is possible to see a similar view as that of Thomas Jefferson, which he deemed was "worth a voyage across the Atlantic" in his Notes on the State of Virginia. ${ }^{1}$ Jefferson further described the view as such:

The passage of the Patowmac [sic] through the Blue ridge is perhaps one of the most stupendous scenes in nature. You stand on a very high point of land. On your right comes up the Shenandoah, having ranged along the foot of the mountain an hundred miles to seek a vent. On your left approaches the Patowmac, in quest of a passage also....It is as placid and delightful, as that is wild and tremendous For the mountain being cloven asunder, the presents to your eye, through the cleft, a small catch of smooth blue horizon, at an infinite distance in the plain country, inviting you as it were, from the riot and tumult roaring around to pass through the breach and participate of the calm below. ${ }^{2}$

Today, visitors to the town might better relate to Thomas Jefferson's vision of pastoral beauty than to the images of the town from the Civil War. From 1859 to 1865 , the history of the town is a story of destruction.

The destruction of buildings, families, and the town's economy shaped the experiences of Harpers Ferry's people between the John Brown's raid and the Civil War. Beginning in 1859, the residents reacted defensively to what they perceived as a threat to their livelihood and to the survival of their households. After 1861, that source of income and wealth in the federal armory and arsenal was destroyed, and the townspeople then were forced to adapt to the changing economic and social circumstances that war and occupation brought to the town. A dread of

\footnotetext{
${ }^{1}$ Thomas Jefferson, Notes on the State of Virginia. With an Appendix, $8^{\text {th }}$ ed. (Boston: 1801), 28.

2 Ibid., 27-28.
} 
destruction and then the actual destruction itself drove townspeople's responses to the conflicts that surrounded them. This sense of destruction also meant that the stable household structure that had lasted for over 60 years in Harpers Ferry could not endure. To cope with the loss of economic prosperity and maintain their households, women reoriented the town's economy to revolve around what war brought: the presence of military troops and officials. Out of this destruction, therefore, townspeople reconstituted their households to survive.

This study seeks to contribute to a greater understanding of Harpers Ferry during this tumultuous period, in which war front and the home front intersected with each other. The histories of Harpers Ferry during this era have generally focused on either events or the outsiders that played central roles in those events. These events include John Brown's raid, the abolitionist attack on the federal armory and arsenal in October 1859, and Colonel Dixon Miles's surrender of approximately 12,000 federal troops to Thomas "Stonewall" Jackson just before the battle of Antietam in 1862 . The problem with focusing on these events alone is that they place the emphasis on outsiders from the town while relegating the townspeople to witnesses, rather than active participants.

Several historians have attempted to write a history of Harpers Ferry throughout the same period as this study. In 960, historian Manly Wade Wellman took the perspective of an older military history-with battles forming the narrative drive of the town in the war. ${ }^{3}$ The second uses a similar approach. However, Charles Hearn tries to incorporate the townspeople into the narrative of the war. Instead of being active participants, however, Hearn treats the townspeople as enduring "six years of hell" that John Brown's Raid and the Civil War had brought to the

\footnotetext{
${ }^{3}$ Manly Wade Wellman, Harpers Ferry, Prize of War (Charlotte, NC: McNally of Charlotte, 1960).
} 
town. ${ }^{4}$ The most recent book about Harpers Ferry and the Civil War is a history that is intended for broad audiences and does not attempt an argument but rather tells the stories of the war with little analysis. ${ }^{5}$ In contrast, this study decenters battles and commanders from the narrative and places the townspeople as key participants who actively shaped defining events. The townspeople did not simply endure or weather the storms of conflict and war. They changed the outcomes.

This study attempts to reach beyond just the historiography of Harpers Ferry itself. I seek to place a greater emphasis on women in wartime and demonstrate how their experiences shaped soldiers' responses and military policy. Stephanie McCurry and Gregory P. Downs both argued that women's petitions to the Confederate government shaped their wartime policy. ${ }^{6}$ Both historians, however, examine the formal petitions to the nation. In this study, I analyze similar negotiations on a local level. Women did not need to plead their case to a national entity; instead, localized negotiations could accomplish those women's goals in a more effective manner. That women could have input on military policies or could convince their occupiers to acknowledge their needs for household survival shows that women's experiences were decentralized and dependent on time, place, and individuals.

By showing how townspeople in Harpers Ferry shaped their own experiences during the war, this study also seeks to contribute to the recent literature about the southern home front and how the war fronts became inseparable from the home front in certain circumstances. Harpers Ferry sat on the border of three different states during the Civil War: Maryland, Virginia, and

\footnotetext{
${ }^{4}$ Charles Hearn, Six Years of Hell: Harpers Ferry during the Civil War (Baton Rouge: Louisiana State University Press, 1996).

${ }^{5}$ Dennis Frye, Harpers Ferry Under Fire: A Border Town in the American Civil War (Virginia Beach, VA: Donning Co. Publishers, 2011).

${ }^{6}$ McCurry, Confederate Reckoning. Gregory P. Downs, Declarations of Dependence: The Long Reconstruction of Popular Politics in the South, 1861-1908 (Chapel Hill: University of North Carolina Press, 2011).
} 
West Virginia (after it achieved statehood in 1863). This location on the Potomac River between the United States and the Confederacy meant that the town faced near-constant occupation. Armies contended over control of the town, and regardless of who was in formal control of it, the unanswerable question of townspeople's loyalties meant that the town was in a constant state of war. As Margaret Creighton has shown, towns became scenes of battles during the war. ${ }^{7}$ In addition, other studies about occupied towns have helped to show this intersection between warfront and homefront. ${ }^{8}$ This study uses these ideas to analyze the border town of Harpers Ferry.

In order to analyze border towns like Harpers Ferry, historians need to examine the warfront and homefront simultaneously. The intersection of warfront and homefront reveals how war shaped towns and how townspeople, in turn, influenced the tide of war. In order to do so, I study household organization, household economy, and military regulation and activity, which all shaped each other during the Civil War in Harpers Ferry. In an occupied setting, the military and the townspeople needed to compromise to achieve mutual benefit and success. Therefore, occupation for Harpers Ferry's people signified a negotiation between the survival of their household and the policies of the military. Civilians and soldiers, contraband and raiders all contribute equally to a deeper understanding of a destroyed town and a townspeople that attempted to shape their own occupation in the midst of war.

\footnotetext{
${ }^{7}$ Margaret Creighton, The Colors of Courage: Gettysburg's Forgotten History: Immigrants, Women, and African Americans in the Civil War's Defining Battle (New York: Basic Books, 2005).

${ }^{8}$ McKenzie Robert Tracy, Lincolnites and Rebels: A Divided Town in the American Civil War (New York: Oxford University Press, 2006); Richard R. Duncan, Beleaguered Winchester: A Virginia Community at War, 1861-1865 (Baton Rouge: Louisiana State University Press, 2007); Jerry W. Holsworth, Civil War Winchester (Charleston, SC: History Press, 2011); Browning Judkin, Shifting Loyalties: The Union Occupation of Eastern North Carolina (Chapel Hill: University of North Carolina Press, 2011); Daniel E. Sutherland, Seasons of War: The Ordeal of a Confederate Community, 1861-1865 (Baton Rouge: Louisiana State University Press, 1998).
} 
The household is vital to understanding the effects of the Civil War on the town of Harpers Ferry and on its townspeople. Historians have emphasized the household of the antebellum period and the Civil War in differing lights. Some utilize the vision of the household as the site of production in Southern society where the head of the household commands the labor of those he considers his dependents. ${ }^{9}$ Others have perceived the household as a physical landscape over which the head of household held authority. ${ }^{10}$ For this study of Harpers Ferry, I have understood the household to be a mixture of both definitions. The household exists as a physical realm that was considered to be under the authority of a male head of household and as a group of persons who collectively ensured the economic survival of all. The two definitions work best when combined: the male head of household held authority over his dependents and used that authority to command their labor.

Gender relations are central to the concept of the household. The idea of an independent white male was the essence of what was masculine, and the very idea of dependency was considered to be feminine. During the Civil War, these distinctions became more blurred; as men were called away from their households to fight, women were left to support the remaining family. As Laura F. Edwards claims, the warfront and homefront intersected as "the Civil War and emancipation shattered the region's households and political institutions with the same blow." 11 This study seeks not just to use the analytical categories of men and women to show the shattering of the household in Harpers Ferry. While the biological sex of the historical actors

\footnotetext{
${ }^{9}$ See Elizabeth Fox-Genovese, Within the Plantation Household: Black and White Women of the Old South (Chapel Hill: University of North Carolina Press, 1988) and Thavolia Glymph, Out of the House of Bondage: The Transformation of the Plantation Household (New York: Cambridge University Press, 2008). Both of these studies utilize plantations as the model for the southern household, which complicates their relevance to Harpers Ferry.

${ }^{10}$ See Stephanie McCurry, Masters of Small Worlds: Yeomen Farmers, Gender Relations, and the Political Culture of the Antebellum South Carolina Low Country (New York: Oxford University Press, 1995).

${ }^{11}$ Laura F. Edwards, Scarlett Doesn't Live Here Anymore: Southern Women in the Civil War Era (Urbana, IL: University of Illinois Press, 2000), 2.
} 
helps to better understand their circumstances during the Civil War, what it meant to be masculine and feminine changed in Harpers Ferry during the Civil War. Instead, gendering as a historical process impacted the household as war emasculated men and gave women increased choice in their own lives.

In this study of household economy and gender, I utilize both the analytical categories of men and women and the historical process of gendering to examine the town of Harpers Ferry. Gender historian Jeanne Boydston argues against the binary analytical cateogires of men/women as the best manner to study gender. Instead, Boydston encourages historians to understand "that gender is not a single, named process" and to "examine more carefully the extent to which and the ways in which gender is a language about power in a given society." ${ }^{2}$ This study uses the gendered binary of man/independent and woman/dependent to explore how events and destruction caused conceptions of gender to shift from their antebellum understanding to a new wartime gender relations. These new gender relations meant that men were not necessarily independent and therefore "masculine" and that women were not dependent on those in their household and therefore "feminine." In the abnormal location of Harpers Ferry, which did not exist as either of the North or of the South, crises like John Brown's raid and the Civil War allowed the townspeople unique opportunities to reshape the town's economy and to reshape occupation. The townspeople made networks with soldiers and subverted the ideals of the household and of gender in order to survive. The greatest contribution of this study, therefore, is to show how the residents of Harpers Ferry shaped their own understandings of gender in the late antebellum period and throughout the Civil War.

\footnotetext{
${ }^{12}$ Jeanne Boydston, "Gender as a Question of Historical Analysis" Gender and History 20, no. 3 (2008): 576.
} 
Chapter One establishes the central role of the federal armory in the antebellum economy of Harpers Ferry. As the main economic force in town, many households were reliant on wage labor from manufacturing. While slaves did live in the town, Harpers Ferry did not have a slavebased economy. Before the war, the town was driven by the ability of one factory to employ over two hundred men, and the dependents of those men can be seen as dependents of the armory as well. In 1859, when John Brown raided the armory and arsenal, the townspeople were not just fighting back against raiders who desired to free the slaves but also defending the economics of their town and the survival of their households. To protect their household, the townspeople engaged in brutal violence against the raiders.

Chapter Two documents the destruction of the armory and arsenal in April 1861. With the central force of Harpers Ferry's economy destroyed within a day of the war, the townspeople were at the mercy of occupying troops. Without the ability to provide for themselves and their dependents, local men lost their sense of independence and their status as heads of households. Occupying troops feminized these local men by removing their authority over the households of Harpers Ferry and by asserting themselves as the new head of household.

Chapter Three focuses on the women of the household, who were most severely affected by the economic destruction and disappearance of men from the town. As a way to survive the turmoil of wartime occupation, female townspeople reoriented Harpers Ferry's economy around the presence of military troops. When they catered to soldiers and military officials in service industries, they effectively changed military policies and shape the occupation of the town. Additionally, when women reoriented their economy, they also chose upon whom they would be dependent. By choosing the military for their head of household, they created household 
networks with the soldiers that forced them to accept responsibilities for the women. In short, these townswomen rebuilt their households and their town out of the destruction of war. 


\section{Chapter One: The Gun-Making Household}

Joseph Barry, who wrote under the alias Josephus, Jr. early in his writing career, first published a history of Harpers Ferry in 1872. The Civil War had concluded less than ten years prior, and yet Barry decided to publish The Annals of Harpers Ferry in nearby Martinsburg, West Virginia. Barry continued to revise his history of the town and, in 1903, renamed it The Strange Story of Harpers Ferry. As can be expected, the history of the town included important events of national interest, such as John Brown's Raid in 1859 and the four years of Civil War. In addition, Barry devoted a significant portion to the earlier history of the town.

Born in Ireland, Joseph Barry emigrated to the United States and held positions as a schoolteacher, a worker in the Census Bureau, and a storekeeper and gauger in the Internal Revenue Service. ${ }^{13}$ From the available records of his life, Barry did not work at the federal armory and arsenal at Harper's Ferry. Indeed, he did not arrive in the town until the armory's final years. Nonetheless, he still took immense pride in the armory and devoted three chapters of his Strange Story to the central role that the armory played in shaping the town of Harpers Ferry. He defined the eras of the town's early history through the officials governing the armory"Civil System", "The Military System," and "The Civil System Again.” At the end, Barry boasts about the capability of the armory and the weaponry it produced: "The capacity of the Harper's Ferry armory was from fifteen hundred to two thousand guns a month, and the muskets and rifles manufactured there were, generally, considered the best in the world." 14 Barry spent more time describing the various superintendents of the armory than any of the mayors or public officials

\footnotetext{
${ }^{13}$ See 1870 and 1880 Census. Bluefield Daily Telegraph, February 2, 1905, page 1. Department of Commerce and Labor, Bureau of the Census. Official Register of the United States, Containing a List of the Officers and Employees in the Civil, Military, and Naval Service. Digitized books (77 volumes). Oregon State Library, Salem, Oregon. Volume 1, page 148

${ }^{14}$ Joseph Barry, The Strange Story of Harpers Ferry, 53.
} 
that governed the town itself. Joseph Barry's history of Harpers Ferry illustrates an important idea about the town in the early republic and antebellum years. For the town's residents, Harpers Ferry was the armory. While auxiliary industries did exist, such as other factories and peripheral businesses, the town was born with the armory, and prosperity depended upon it.

While other men and women living in the town might have disagreed with Barry's focus on armory superintendents as the leaders of the town, the town's economy undoubtedly was reliant on manufacturing, and the townspeople depended upon it in some way for their livelihoods. Slavery, while present, was not the economic linchpin as in the other regions of the South. The coexistence of slavery and wage labor in Harpers Ferry created a unique environment for the townspeople who would face crises with their system during John Brown's raid and the Civil War. For those who lived through John Brown's raid on the federal arsenal and armory, the attack was both on the armory itself and on the institution of slavery. The brutality of the townspeople during the raid can be best explained through examining both the reliance of townspeople on the armory and the dynamics of race.

Historians have previously examined the coexistence of wage labor and slavery. During the early republic era, Baltimore's wage laborers and slaves often worked side-by-side and in similar conditions. However, these wage laborers were often unskilled and therefore could not achieve any ideal of independence in the industries available to them. In Baltimore, then those on the lowest rungs of society were left little choice or opportunity for independence and social mobility. ${ }^{15}$ In a study about antebellum Georgia, Michele Gillespie asserts that white artisans "occupied an ambiguous place in the antebellum social order" and were denigrated by the presence and labor of slaves. In a slaveholding society that marginalized physical labor, white

\footnotetext{
${ }^{15}$ Seth Rockman, Scraping By: Wage Labor, Slavery, and Survival in Early Baltimore (Baltimore: The Johns Hopkins University Press, 2009), 1-12.
} 
artisans were given little respect by elites in their communities. This analysis concludes that the system of slavery prevented a white working class from emerging in the antebellum South. ${ }^{16}$ In both studies, slavery and wage labor coexisted but only fretfully. The presence of slavery stifled and denigrated white wage workers. The implication in these studies is that a white working class in a society could not establish household independence in a slave-based economy. White wage laborers struggled to distinguish themselves from the dependence of slaves and free blacks.

Harpers Ferry, on the other hand, offers an interesting case of wage labor flourishing in antebellum Virginia. The economy of the town differs significantly from what might be assumed of the antebellum economies of similarly sized towns. This difference came from several factors. First, the federal government invested in the construction and maintenance of two large-scale armories as well as an arsenal. At the time of its establishment and productivity, the armory at Harpers Ferry was only one of two in the United States. The lack of another similar institution within the South meant that Harpers Ferry would remain distinct from other styles of economy. Second, the mountainous terrain surrounding the town meant that few townspeople were actively engaged in farming. On the outskirts of the town, farming was common. However, the townspeople who worked in the armory did not often attempt large-scale farming. As a result of the government investment in manufacturing at Harpers Ferry and the poor farming terrain of the town, the economy of Harpers Ferry was reliant upon wage labor, and many families depended upon wages from the federal government.

The families and their wages were prominent in the town of Harpers Ferry. The structure of these households plays a prominent role in how changes in the economy affected the population of Harper's Ferry. Gender historians have described the household as the foundation

\footnotetext{
${ }^{16}$ Michele Gillespie, Free Labor in an Unfree World: White Artisans in Slaveholding Georgia, 1789-1860 (Athens: University of Georgia Press, 2000), xvii-xxii.
} 
of southern society. The roles in which men and women were situated and the racial contest of authority over black men and women played out within this central unit. Elizabeth Fox-Genovese characterized the household as a unit of people that pooled income and resources. This does not mean that households were drawn around the concept of family or familial relationships; in this definition of the household, dependents also included the women, children, and slaves who were under the ultimate authority of the male head. ${ }^{17}$ The household and its economy was not necessarily a consensual relationship between the head and his dependents; slaves were coerced by violence to contribute their labor, and there was little recourse for women who sought to end their marriages. Rather, this analytical unit was marked by the mastery of men and the subjugation of all others.

The community of Harpers Ferry tests these ideas of the household as a fundamental unit for southern society. The town's economy, centered on manufacturing, does not fit into FoxGenovese's description of southern society and the resulting southern household, which formed from an economy that was "in but not of the bourgeois world" and prevented the spread of the capitalism. ${ }^{18}$ According to this definition, the household functioned as a bulwark against industrialization and was distinct from the northern idea of the "home" in which the head of household brought his wages and women were excluded from productive labor. ${ }^{19}$ Harpers Ferry does not fit the criteria for southern society as outlined by Fox-Genovese. The federal armory and arsenal as well as the private manufacturing that thrived in the water-powered town both infused Harpers Ferry's economy with wage labor, which was significantly different from the

\footnotetext{
${ }^{17}$ Elizabeth Fox-Genovese, Within the Plantation Household: Black and White Women of the Old South (Chapel Hill: University of North Carolina Press, 1988), 31.

${ }^{18}$ Ibid., 55.

19 Jeanne Boydston, Home and Work: Housework, Wages, and the Ideology of Labor in the Early Republic (New York: Oxford University Press, 1994).
} 
agriculture, slave economy in other areas of the South. Despite this link with northern manufacturing and northern bourgeois sentiments, one must be careful not to lump the town into northern society and capitalist market. In particular, these similarities with wage labor does not mean that Harpers Ferry and its people would identify with that regionalism or that unfree labor did not exist within the town.

The presence of slavery differentiates Harpers Ferry from any strict comparisons to northern towns or cities. The coerced labor of 150 slaves coexisted with the armory's wage laborers within the town, which cannot be said for any northern town just before the onset of the war or during the war. These slaves and the substantial presence of slavery in the surrounding countryside and in other towns in Jefferson County shaped the household of Harpers Ferry. Just as Fox-Genovese describes southern society and the resulting household as influenced by the emerging capitalism of the North and linked to its economy, Harpers Ferry is better described as influenced by the surrounding area and its location in the state of Virginia. Therefore, while the town did benefit from an industrialized economy with wage labor, it cannot be described as a northern town and its households fit fretfully between the ideals of a northern home and a southern household.

By looking at population and employment statistics for the townspeople, Joseph Barry's conflation of the town's history with the armory's history makes more sense. The town existed prior to the establishment of the armory, but it was extremely small and mainly consisted of private land belonging to Robert Harper, who ran a ferry across the Potomac River. According to Joseph Barry, during George Washington's administration, the federal government chose Harper's lands for the site of the second federal armory and arsenal because of the "immense" water-power. Barry wrote that the first superintendent arrived in the town in 1806 when "the 
town was yet in its infancy, with very few denizens. ${ }^{20}$ Historian Merritt Roe Smith agrees with Joseph Barry's assessment of the town. Smith characterizes the federal government's choice of Harpers Ferry for the federal armory as plagued by the town's status as "little more than a trading outpost occupied by a handful of residents." ${ }^{21}$ The gun-making industry grew even more entrenched in 1818 when John H. Hall arrived in Harpers Ferry and set up an additional factory on Virginius Island, just outside of the town limits, to manufacture his interchangeable guns. ${ }^{22}$ During this period of growth, Smith asserts that the armory was illustrative of the anxieties surrounding large-scale manufacturing. In addition, Smith claims that Harpers Ferry represented in those years "an isolated rural society floundering between two worlds of agrarian pastoralism and industrial progress." ${ }^{23}$ By 1860, however, that tension between agrarianism and manufacturing had been resolved on the side of industry. Many more townspeople self-identified as working within the armory than in any sort of agrarian occupation.

A significant source of information about the armory's economic presence can be gathered from the census. In particular, the census conducted in 1860 provides a glimpse into the occupations and structures of households in Harpers Ferry. ${ }^{24}$ The structure of households in the census allows historians to see how families supported themselves. As such, the selfidentification of townspeople's employment shows how they define their own occupations and what they considered to be vital to their family's survival. These occupations that men and women cited to the census worker did not conform to a set standard - a wage laborer in the

\footnotetext{
${ }^{20}$ Barry, 16-17.

${ }^{21}$ Merritt Roe Smith, Harpers Ferry Armory and the New Technology: The Challenge of Change (Ithaca, NY: Cornell University Press, 1977), 33.

${ }^{22}$ Barry, 23-24.

23 Smith, 21-22.

${ }^{24}$ I have combined the towns of Harpers Ferry and Bolivar for the sake of clarity. While they existed as separate incorporations and had separate enumerations for the census, I refer to both Bolivar and Harpers Ferry when discussing a more generic "Harpers Ferry."
} 
federal armory was described either as an "armory employee," "armorer," and even more specific jobs like "polisher of gun bands" and "filer on guns." 25

However, despite the benefits of workers identifying their own occupations, there are still significant disadvantages to their self-characterizations. This self-identification tended to emphasize men's occupation over women's domestic work. The favoring of male labor over female work demonstrates the gender dynamics in the household as well. As Jeanne Boydston has argued, the feminine work of childraising and domestic labor was increasingly devalued as women's work did not earn wages. ${ }^{26}$ These gendered dynamics surrounding paid and unpaid labor meant that women's work was rarely included in the census as contributing to household survival. However, these blank spaces for female labor does not mean that women did not labor. Instead, the generic occupation of "keeping house" for women benefited those households in significant ways. As women cooked, sewed, tended gardens, raised livestock, and raised children while their husbands worked in the armory, they contributed to the survival of their household as well. While these domestic labors were not seen as an occupation to census takers, it is a mistake to marginalize this labor from what kept the households of Harpers Ferry functional. However, historically, American society perceived women's labors as unproductive, so therefore, the occupation records skew towards men's labor and contribute to a general assumption that men's wage labor in Harpers Ferry was the sole source of income for the towns' households.

\footnotetext{
${ }^{25}$ This discrepancy in the descriptions of the job makes it difficult to determine exactly how many people were employed in the federal armory. The term "machinist" could either refer to a worker in the federal armory or other factories in Harpers Ferry. For clarification and simplification, I have chosen to only include those people whose occupation directly points to the armory as their employer. Any mention of the armory, government, or guns was used to signal government employment. This means that any machinists were excluded from the count, despite the potential that they were also employed there. As such, the number and percentages of armorers in the town likely trends on the conservative side.

${ }^{26}$ Boydston.
} 
Even with this eventual skewing of labor in Harpers Ferry, the census provides data about the households of the town that is unavailable elsewhere. While records from the armory itself document the number of employees, those records cannot accurately describe how dependent the town itself was on the armory in its economy. Instead, the 1860 census can demonstrate not just the employees but also the number of dependents in those employees' households. By looking at the economy in this way, it better shows how the federal armory was the central force in Harpers Ferry's economy. In addition, the census records illustrate how many more people were reliant upon federal wages than on enslaved labor. Indeed, the town was increasingly more tied to the federal government than to the institution of slavery.

By 1860, the federal armory and arsenal employed over 200 employees, according to the federal census taken in that year. ${ }^{27}$ Approximately 2,300 people lived in the area of Harpers Ferry. At first glance, 200 armorers out of a total population of 2,300 does not appear to be the main driving force of the economy. However, those armorers took their wages home to their wives, children, and other dependents. It was not just those 200 armorers who were tied directly to those wages but also their dependents who depended upon money for their household survival. If those dependents are included in the general count of those directly dependent on the federal government for wages, the number of those directly tied to the armory jumps to over 1000. Just under half of the population of Harpers Ferry depended upon federal wages. Even more significantly, that $44 \%$ of Harpers Ferry households reliant on wage labor does not include the storekeepers, tavern owners, or boardinghouse keepers whose businesses depended upon receiving those wages. While that statistic is not as that of armorers and their dependents, it is

\footnotetext{
${ }^{27}$ The precise number of employees listed in the census is 234 , but that number is on the conservative side. The employees were compiled using the Bolivar and Harpers Ferry records but did not include the "not specified" part of Jefferson County, Virginia. Some employees could have lived outside of the townships and therefore were not included. Therefore, the demographics of the households in Harpers Ferry tend toward a conservative estimate.
} 


\begin{tabular}{l|l|l|l} 
& Harpers Ferry & Bolivar & Total \\
\hline Armorers & 108 & 126 & 234 \\
\hline $\begin{array}{l}\text { Armorers and } \\
\text { Dependents }\end{array}$ & 469 & 582 & 1051 \\
\hline Total Population & 1251 & 1103 & 2354 \\
\hline $\begin{array}{l}\text { Percent of Those With } \\
\text { Direct Connection to } \\
\text { Armory }\end{array}$ & $37.5 \%$ & $52.8 \%$ & $44.6 \%$ \\
\hline
\end{tabular}

Source: 1860 Federal Census, Harpers Ferry and Bolivar Townships, Jefferson County, Virginia

probable that the wages from the federal armory were also supporting those auxiliary businesses and their related households in an indirect manner. ${ }^{28}$

The town's households were dominated by the presence of armorers as the head of household and, therefore, the person in the position of authority over the dependents. However, households in Harpers Ferry cannot be simply confined to those examples. Roughly $85 \%$ of residents in Harpers Ferry lived in households headed by men, but there was a significant portion of the population that lived with women described as the head of household in the census. Approximately 360 people were living in these households in Harpers Ferry. ${ }^{29}$ In the conceptions of the household, these women's status as head of household meant that they would be the one commanding the labor of their dependents and that these women could be considered to be the independent person or the masculine person of the family. The presence of female-headed household destabilizes the assumption of Harpers Ferry as being the domain of white wage laborers.

\footnotetext{
${ }^{28} 1860$ United States Federal Census, population schedule, Harpers Ferry and Bolivar Townships, Jefferson County, Virginia, accessed through Ancestry.com (Provo, UT: Ancestry.com Operations, Inc., 2009), originally from United States of America, Bureau of the Census, Eighth Census of the United States, 1860 (Washington, D.C.: National Archives and Records Administration, 1860).

${ }^{29}$ Ibid.
} 
However, these women who headed their own households were frequently described in the census as being without an occupation. 64 households were listed as having a head with no occupation, which represents $80 \%$ of female-headed households. The remaining others listed their heads as having occupations that matched with women's unpaid domestic labor. There were seven boarding house keepers, two dressmakers, a washerwoman, and two milliners. Two elderly women even described themselves simply as a "lady." Census workers only listed two as being outside of traditionally feminine occupations: one woman was listed as a merchant and another as a schoolteacher. ${ }^{30}$ Despite these women having listed occupations in a time when the census was disinclined to include them, women with occupations only represented $20 \%$ of femaleheaded households and 3\% of all the households in Harpers Ferry. Most households in Harpers Ferry were headed by men, who were frequently employed by the federal armory, but women with listed occupations and as the head of their own household meant that there was some opportunity in the antebellum period for women to survive outside the more common maleheaded household.

Aside from their economic and demographic predominance, another important detail about the households of the armorers is that they were almost universally white. The number of free blacks in Harpers Ferry amounted to 113; however, none of them are listed with any occupation in the federal armory, so none of them would be included in the percentage of the population with a direct connection to federal wages. With the approximately equal number of slaves in Harpers Ferry, there existed about 230 people who were excluded from the potential for

\footnotetext{
${ }^{30}$ Ibid.
} 
federal employment based on their race. In other words, about a tenth of the population of Harpers Ferry could not work for the federal armory. ${ }^{31}$

There is no clear answer as to why free blacks and slaves were barred from employment, but the factory floors of the armory were marked as white. From this demographic information, it becomes clear that the armory was the province of white men. The prosperity of Harpers Ferry's economy was directly linked to the wage labor of white men, rather than the slave labor that characterized other portions of the South. Simply put, the fact that the total employees in the armory outnumbered the total number of free and enslaved blacks illustrates that Harpers Ferry, Virginia was not based on slavery but on wage labor.

However, slavery did exist in Harpers Ferry but at a low frequency. Roughly 5\% of the total population was enslaved, and only $12 \%$ of households owned slaves. In addition, these slave-owning households rarely held more than one or two slaves; the average number of slaves per household was just 2.25. James S. Welch, listed in the census as a miller, owned the most slaves in the town with a total of only 8 . Harpers Ferry did not have either flourishing slave or slaveowning populations. Instead, slavery was a smaller part of the wage labor economy of Harpers Ferry. ${ }^{32}$

However, the wage labor and slavery aspects of the manufacturing-based economy did overlap at times. Seventeen armorers owned slaves. While this is not a significant percentage of the number of armorers in the town, it does not mean that wage labor and enslaved labor mixed. Most of the armorers who owned slaves were those in high positions. Alfred Barbour, the last

\footnotetext{
${ }^{31} 1860$ United States Federal Census-Slave Schedules, Harpers Ferry and Bolivar Townships, Jefferson County, Virginia, accessed through Ancestry.com (Provo, UT: Ancestry.com Operations, Inc., 2010), originally from United States of America, Bureau of the Census, Eighth Census on the United States, 1860 (Washington, D.C.: National Archives and Records Administration, 1860).

${ }^{32}$ Ibid.
} 
superintendent of the armory, owned four slaves, although three were listed as fugitives in the slave schedule. John E. P. Dangerfield, a paymaster's clerk, owned five. Dangerfield was taken hostage during the raid of the armory and arsenal by John Brown, who targeted significant members of Harpers Ferry and the surrounding countryside. Despite these high-ranking armory officials, only $7 \%$ of armory employees owned a slave. That percentage is larger than the community at a whole, however; only $2 \%$ of the population owned a slave. ${ }^{33}$

This glance at the demographics of Harpers Ferry demonstrates important characteristics of its society just before the start of the Civil War. First, a little under half of the population directly depended upon the wages that were earned on the floor of the armory. Second, all blacks were excluded from government employment, which made the armory into a space reserved for white men. Lastly, while slavery was present in Harpers Ferry and some wage laborers did own slaves, the town's economy was not reliant upon enslaved labor. The number of slaves and of slaveowners were simply not adequate for the institution of slavery to be a mainstay of the economy of Harpers Ferry.

However, even if slavery was not the driving force of the economy in Harpers Ferry, that does not mean that the townspeople were not interested in preserving it. After all, slaveowners regularly sold their enslaved property and put out runaway ads in the Virginia Free Press, the newspaper run in nearby Charles Town. Regardless of the lack of economic potential for slavery in the town, there were other possible reasons to defend the institution. As David Roediger describes, the presence of slavery helped white workers to feel more secure in their form of wage labor. By denigrating other group of people to a worse status than themselves, white workers

\footnotetext{
${ }^{33}$ Ibid.
} 
could feel better about their lack of traditional independence. ${ }^{34}$ While Roediger describes the dynamics in northern cities, his assessment could also fit the manufacturing town of Harpers Ferry. Put in the light of anxieties about the failure to achieve masculine independence, the exclusion of all black workers from the armory seems to fit into Roediger's analysis of white workers. By creating a white masculine zone in the armory, the armorers might have created a sense of independence through denying other races the privilege to earn a working in that way. It is not just that free blacks and slaves did not work in the armory; instead, white workers had something to gain from excluding them from such employment.

Beyond white workers feeling more secure with their wage labor, slaveholding also served another purpose in southern society and in Harpers Ferry. Slaveholding was as much a status symbol as it was an economic decision. For a white man to own a slave, it signified that he was prosperous and successful. As Walter Johnson described it, a potential slaveholder imagined how their lives would be different with a slave in their household. Indeed, they imagined how they themselves would be altered by owning slave property. ${ }^{35}$ In Harpers Ferry, then, slaveholders benefited from their status that came from owning even one slave, even if they did not operate large-scale plantations that needed many slaves. Instead, by having a slave replace some of the labor for his wife or contribute in a smaller way to the income of the household, independent white men could claim a higher status. Slavery might not have been the economic driving force in Harpers Ferry, but the subordination of black men and women allowed white men to claim a firmer position in their society and as head of their households.

\footnotetext{
${ }^{34}$ David R. Roediger, The Wages of Whiteness: Race and the Making of the American Working Class (London: Verso, 1991).

${ }^{35}$ Walter Johnson, Soul by Soul: Life Inside the Antebellum Slave Market (Cambridge: Harvard University Press, 1999), 79.
} 
The dual nature of Harpers Ferry as a slaveholding town and as a manufacturing center went hand-in-hand during the major crisis of the antebellum era in the town. This combination drew John Brown to the town and created the perfect situation for the attempted raid against the South and the institution of slavery. Brown planned for the guns that were stored in the arsenal to arm slaves and free blacks from the surrounding area and to be the basis of a widespread slave rebellion that would weaken the overall institution. ${ }^{36}$ The other option of a federal arsenal to raid was in Springfield, Massachusetts where the opportunity for slave and free blacks flocking to join in the insurrection did not exist. Therefore, even with the relatively low presence of slaves within Harpers Ferry, the existence of any was important for John Brown's perception of the town, armory, and arsenal.

John Brown's raid has defined the history of Harpers Ferry. The attack on the armory seized headlines across the nation. Traditionally, historians have looked either biographically at the motivations of John Brown and his followers or at the various reactions to the trial. Several biographies have been written about Brown himself, and they usually seek to explain why John Brown attempted the raid. ${ }^{37}$ For these historians, the reactions of the townspeople are seen in response to the raiders and their abolitionism, as the story is centered around their actions. Conversely, historians have also studied how both northern and southern peoples reacted to the attempted insurrection. This focus on outsiders' reactions place the raid in a national debate between slavery and antislavery. For these historians, the events that occurred in Harpers Ferry

\footnotetext{
${ }^{36}$ Stephen B. Oates, To Purge This Land with Blood: A Biography of John Brown (Amhearst, MA: University of Massachusetts Press, 1970), 276-9.

${ }^{37}$ See Oates, To Purge This Land With Blood, Tony Horowitz, Midnight Rising: John Brown and the Raid that Sparked the Civil War (New York: Henry Holt and Co, 2011), Oswald Garrison Villard, John Brown, 1800-1859: A Biography Fifty Years After (Gloucester, MA: P. Smith, 1966), David S. Reynolds, John Brown, Abolitionist: The Man Who Killed Slavery, Sparked the Civil War, and Seeded Civil Rights (New York: Alfred A. Knopf, 2005), Benjamin Quarles, Allies for Freedom: Blacks and John Brown (New York: Oxford University Press, 1974), and Evan Carton, Patriotic Treason: John Brown and the Soul of America (New York: Free Press, 2006).
} 
mattered most when those outside of the town responded to it. This perspective emphasizes the meaningful of John Brown's raid in polarizing national debates. ${ }^{38}$

One perspective that is missing in these analyses of John Brown's raid is that of the people taken by surprise. These townspeople awoke on the morning of October 17, 1859 to find their town and their main source of income invaded by men who had pretended to join the surrounding community. As the armorers traveled to work on that Monday morning, they were taken hostage as they arrived. In total, on the morning of October 17, some 40 men had been taken hostage, although some would be released when the raiders were forced back into the fire engine house of the armory complex by local townspeople and militia units. ${ }^{39}$ The final hostages, who were only freed after the storming of the engine house by U. S. Marines, were chosen because of their prominence in the town. Out of the ten hostages held by John Brown and his dwindling band of raiders were four armory employees. Three of these were high officials: Benjamin Mills, who was the master armorer; Armistead Ball, the master machinist; and John E. P. Dangerfield, the paymaster's clerk. Also taken hostage was George Washington's great grandnephew, Lewis Washington and John Allstadt and his son, all three of whom were planters from the surrounding areas and had been specifically targeted by John Brown. ${ }^{40}$ While Brown had sent his men to capture Washington and the two Allstadts, the capture of the high officials of the armory likely took place on the morning of October 17 and was an opportunistic capture.

\footnotetext{
${ }^{38}$ See John Stauffer and Zoe Trodd, The Tribunal: Responses to John Brown and the Harpers Ferry Raid (Cambridge, MA: Belknap Press of Harvard University Press, 2012) and Paul Finkelman, His Soul Goes Marching On: Responses to John Brown and the Harpers Ferry Raid (Charlottesville, VA: University Press of Virginia, 1995). Also notable is Stephen Vincent Benét's epic poem, John Brown's Body, which describes the raid and the entire Civil War in verse and won the Pulitzer Prize in 1929. Stephen Vincent Benét, John Brown's Body (Chicago: Elephant Paperbacks, 1990, reprint).

${ }^{39}$ John H. Zittle and H. Minnie Zittle, The Correct History of the John Brown Invasion at Harper's Ferry, West Va., Oct. 17, 1859: Compiled by the late CAPT. JOHN H. ZITTLE, of Shepherdstown, W. Va., Who Was an Eye-Witness to Many of the Occurrences, and Edited and Published by His Widow (Hagerstown, MD: Mall Publishing Company, 1906), 32.

${ }^{40}$ Oates, To Purge This Land with Blood.
} 
However, the fact that Brown retained these men after he let some thirty others go makes it appear likely that he knew of their importance to the town. Even with the townspeople who were taken hostage during the raid, the response of townspeople to the invaders in their town and their armory colleagues being taken hostage matters to the overall story of the raid. To understand the general impact of the raid on the town itself, historians need to look at what the townspeople believed they were confronting.

Over the course of October 17 and 18, 1859, townspeople and local militias converged to fight John Brown and his raiders. While confronting these invaders, the civilians of Harpers Ferry and nearby towns committed brutal acts of violence against the raiders. Whether through killing raiders who were not armed or mutilating their dead bodies, the townspeople expressed their rage through these acts of violence. It should not be taken for granted that these people were reacting simply to invaders or to abolitionists. The nature and source of the violence needs to be examined to fully understand why the townspeople reacted in such ways. The raid, however, was not simply townspeople harming the raiders. Instead, a battle of sorts occurred between the two groups, although the townspeople and the local militia groups greatly outnumbered the raiders.

The demographics of the town are important when examining how the townspeople reacted to John Brown. As shown, slavery was not vital to the town's economy, but the institution was still present in Harpers Ferry. Therefore, slaveowners would most likely react in extreme ways to a potential slave insurrection. However, with only 51 slaveholders living in the town itself, it is necessary to look beyond just slavery as the cause of the townspeople's violence. Instead, it is also important to reiterate how many armory employees lived within the town. In a town so dominated by manufacturing and, in particular, one factory complex, a raid against that complex might be tantamount to an attack against the livelihoods of those employees. These 
demographics point to another way in which to consider townspeople's actions. They reacted both to the attack against the armory itself and to the presence of abolitionists in their town.

This question of whether the armorers were reacting to the raid as an attack on the armory or on slavery reduces to a more simplistic question of when the townspeople learned that John Brown was in their town and that he sought to free their slaves. Due to the nature of records, however, this latter question proves to be much harder to answer definitively. The timelines presented in different sources varied about when the townspeople realized that it was an abolitionist attack. On the train stopped by John Brown and his raiders in the middle of the night on October 16-17, passengers believed that the men were, in fact, robbers who intended to rob the federal government's treasury. ${ }^{41}$ The clerk of the Wager Hotel, W. W. Throckmorton, originally thought that the raiders were simply a "gypsy wagon" that was passing during the night. However, later, when Throckmorton received a note to bring breakfast for the hostages, he said it had come from a "Captain Smith," but without explanation in his statement, Throckmorton switches to referring to Captain Smith as Brown and to conversations about his intention to free the slaves. ${ }^{42}$

The confusion had not cleared up by the next morning. In her article published later in 1902, Jennie Chambers described how the rumors about the raiders spread throughout the town. Chambers spoke to one of her classmates, who told her that it was "the Abolitionists." She also recounts how a neighbor of hers misheard a man and thought that the gunshot noises were due to a "wild beast." ${ }^{, 43}$ However, David Hunter Strother contradicted Chambers's narrative of events. On the third and ending day of the raid, October 18, Strother arrived in Harpers Ferry to draw the

\footnotetext{
41 Zittle, 26.

42 Ibid., 22-23.

43 Jennie Chambers, "What a School-Girl Saw of John Brown's Raid," Harper's Monthly (1902).
} 
raiders as he was a noted newspaper sketch artist. At the time that he arrived, Strother believed that the invaders were simply "a band of vulgar robbers who had come to possess themselves of the Paymasters [sic] strong box" and intended to use the uproar around a slave insurrection as a distraction. Strother noted that if the townspeople had known that it was John Brown in their town, "he would not be permitted to live five minutes." 44 Joseph Barry, in his history of Harpers Ferry, also discussed the uncertainty of identifying the raiders. As Barry described it, "Madam Rumor had plenty of employment for her hundred tongues"; additionally, Barry does not shed any light on how the townspeople discovered that the raiders were actually abolitionists but stated that "in some way," the information was released. ${ }^{45}$

Throughout these different sources, there exist competing timelines of when the townspeople found out the identity of the people who had captured the armory and arsenal and taken hostages in Harpers Ferry. There is likely not a clear answer to be found from historical documents to illuminate the precise time; instead, historians must grapple with the uncertainty left by these contradicting narratives. ${ }^{46}$ This conflict of timelines complicates the question of why the townspeople reacted with brutal violence. If the townspeople had discovered the motivations of the raiders on October 18 , like Strother claimed, it would mean that their brutality towards the raiders might not necessarily be about slavery at all. Conversely, if the identities of the raiders became well-known throughout the town early on October 17, that would place the townspeople's reactions in a very different perspective. Then, the townspeople might be reacting to the threat against the institution of slavery. These differing scenarios make determining the

\footnotetext{
${ }^{44}$ David Hunter Strother Papers, A\&M No: 2894, West Virginia Regional History Center.

${ }^{45}$ Barry, 63.

${ }^{46}$ Cecil B. Eby accepts the perspective of Jennie Chambers and asserts that Strother's claim that the townspeople were not aware of Brown's identity was not generally shared in the town. However, Chambers's reputability should also be questioned as she made several false statements in her article that was written forty years after the events. See note 8 in Cecil B. Eby, "The Last Hours of the John Brown Raid: The Narrative of David H. Strother," The Virginia Magazine of History and Biography 73, no. 2 (1965): 171.
} 
timeline of when the townspeople learned of John Brown vital to explaining why Dangerfield Newby was mutilated after death and why the two bodies of William Leeman and William Thompson were left in the Potomac River and used for target practice.

Dangerfield Newby was the first raider to die on the morning of October 17. Newby was a former slave who had been attempting to purchase his wife and six children when their owner threatened to sell them South. In his pocket on the morning of October 17, Newby carried letters from his wife, which begged him to act quickly. ${ }^{47}$ Sometime that morning, Newby stood near the gate to the armory and was shot by a townsperson who later claimed to have shot him with a smoothing iron, according to Joseph Barry. Newby's body was not collected for over a day. In the evening of October 18, Barry saw one man shoot the dead body of Newby and another kick his face. ${ }^{48}$ David Strother also recounts the townspeople's actions toward Newby's body. When Strother arrived on the morning of October 18, he described a grisly scene: "In the street, near the old arsenal lay the bloody corpse of a Negro whose glassy staring eyes and fallen jaw was hideous to behold. A dog was smelling the map of coagulated blood which surrounded his head and a couple of pigs were rooting at the body." Surrounding this gore and other dead bodies was a crowd held back by a US marine. One man, who was escorting two women, allegedly said to the surrounding crowd, "Can't you stand back and let the ladies see the corpses?"49 To understand why his body was not moved for so long, it must also be considered that for the majority of the time, there was active fighting around the area. Newby's body lay at the entrance to the armory complex, just before the engine house where John Brown, the remaining raiders,

\footnotetext{
${ }^{47}$ Letters from Harriett Newby, dated April 11, 1859, April 22, 1859, and August 16, 1859, in Calendar of Virginia State Papers and Other Manuscripts from January 1, 1836 to April 15, 1869; Preserved in the Capitol at Richmond, vol. XI (Richmond, 1893), 310-311.

${ }^{48}$ Barry, 94-96.

${ }^{49}$ Strother.
} 
and their hostages were located. However, by the time that Strother arrived in the town to sketch a portrait of John Brown, the raid had been over for several hours. In those several hours without shooting or active fighting, the townspeople had not moved his body yet but treated it as a spectacle. Undoubtedly, his skin color and race caused the Southern people to be less inclined to move his body, but it was not just the black raiders who were treated in such a way.

Dangerfield Newby was, most likely, the second person to die in the raid; the first was Heyward Shepherd, a free black baggage handler for the railroad who was killed during the first night of the raid. Shepherd's injury and eventual death did not create a frenzy for the townspeople's mob, however. It took the death of the town mayor, Fountain Beckham, to whip the townspeople into a frenzy. After a raider shot and killed Beckham, townspeople stormed the Foukes Hotel, where a raider named William Thompson was being held with the townspeople's intention to hand him over to the authorities. Christina Fouke, the sister of the hotel keeper, attempted to stop the civilians from seizing Thompson, but the townspeople took the prisoner to the railroad bridge over the Potomac River and shot him there. ${ }^{50}$ Thompson dropped down into the river, and as his body lay in the Potomac River, the townspeople and militiamen used Thompson's corpse as target practice. Like they had with Newby's body, the townspeople did not retrieve Thompson's body for several days. ${ }^{51}$

The residents of Harpers Ferry used another dead body as target practice as well. William Lehman was attempting to escape across the Potomac River when he was shot while in the river. He was not killed by the first shots but rather laid on a rock in the middle of the river, apparently wounded. A civilian waded out into the waters and shot Lehman in the head. ${ }^{52}$ David Hunter

\footnotetext{
${ }^{50}$ Barry, 68-69.

${ }^{51}$ Strother.

${ }^{52}$ Barry, 70-71.
} 
Strother described both Lehman's and Thompson's bodies in the Potomac River after the end of the raid. The militiamen and the townspeople were a "half armed, half drunk, and noisy" mob who shot at "three dead bodies" in the Potomac River "for their amusement."

Joseph Barry attempted to justify these two killings by the townspeople. For the killing of William Thompson, Barry claimed that the "excitement caused by Mr. Beckham's death" moderated the fact that "the killing of this man was unnecessary. ${ }^{, 54}$ Beckham's death, according to Barry, had caused just a frenzy among the townspeople that, in his mind, they were not truly responsible for killing an unarmed man that had already been taken prisoner and was under their control. As for Lehman's death, Barry attempted to justify the townspeople's conduct by claiming that the killer resided in another county and was not actually from Harpers Ferry. According to Barry, the death of Lehman was "an act of great barbarity, as he had made signs of a desire to surrender." However, Barry was clear to point the blame not on the residents of Harpers Ferry but on external factors - either the death of a beloved mayor or on the excitement of an outsider.

Despite Barry's reassurances that the brutal actions of townspeople could be explained away by the circumstances, the townspeople did not refrain their violence to dead bodies. In the case of Jeremiah Anderson, at least two townspeople were violent as he was dying from bayonet wounds. Anderson had remained in the engine house until the U. S. Marines arrived on Tuesday morning and stormed the building. The Marines stormed with bayonets to prevent injury to any of the hostages. In the siege, Anderson was stabbed with bayonets several times in the stomach and chest. When David Strother arrived, he saw Anderson "wallowing in death spasms" and guarded by a marine who "protected the dying wretch from disturbance" against the crowd that

\footnotetext{
${ }^{53}$ Strother.

${ }^{54}$ Barry, 92.
} 
was pressing in to see him dying. ${ }^{55}$ Joseph Barry described Anderson as "vomiting gore" and one townsperson as having "squirted tobacco juice and dropped his quid" in Anderson's eye as he was dying. Later, doctors from another town forced his body into a barrel, in order to use it later for a dissection. According to Barry, townspeople watched as the doctors broke his bones in order to fit him into the barrel, which "elicited the warmest expressions of approval from the spectators." $" 56$

For the final three raiders discussed, the brutality against their dead bodies occurred after the capture of John Brown and his still-living raiders. Additionally, while the two AfricanAmericans, Dangerfield Newby and Jeremiah Anderson, were subjected to the worse treatment at the hands of the townspeople, whiteness did not save William Thompson and William Lehman from being killed when unarmed or being mutilated after death. Instead, the townspeople unleashed their anger at anyone related to the raid, regardless of color. Looking at all four deaths and the treatment of their bodies demonstrates that it was not just animosity toward former slaves or free blacks that prompted the townspeople to commit acts against corpses. Instead, the animosity went beyond being simply motivated by race.

Instead, the demographics of the town were important to understanding how the townspeople reacted to the raiders and to the events. John Brown and his men had barricaded themselves, high-ranking armory officials, and prominent slaveholders into the building that served the purpose of storing fire engines to prevent the destruction of the armory's workshops. They took control of a building within the armory complex and took men hostage as they reported for work. Added to that, former slaves and free blacks joined them in gaining access to a space that had been strictly reserved for white men. In the situation presented by John Brown

\footnotetext{
${ }^{55}$ Strother.

${ }^{56}$ Barry, 93-94.
} 
and his fellow raiders, it was the combination of the attack against the armory and against slavery. For the townspeople, it was both a threat to their households' survival and to the privileges of whiteness. They were not fighting to retain their slaves, as few of them owned any. They committed brutal acts against the dead bodies of raiders because they represented the dual threat against the foundation of the town's economy and the town's racial hierarchy. In short, the townspeople's reactions were influenced by both their economic dependence on the armory and by the presence of racial slavery in the town.

John Brown's raid constituted the first real threat to the institution of the federal armory and arsenal at Harpers Ferry. Prior to the raid, the armory had a stable position within the town's economy. While there had been turnover and turmoil in the armory's history, ${ }^{57}$ those episodes in the town's history did not represent a direct threat to the armory's continued existence. Instead, those conflicts dealt with differing opinions of how the armory should operate. John Brown's raid, on the other hand, was a violent act against the townspeople and their primary place of employment.

After the end of the raid, the local authorities placed the armory and the town under greater surveillance. Nearby militia units regularly patrolled the area, watching for another John Brown to strike against the armory. ${ }^{58}$ In addition, the U. S. Army placed roughly 40 troops at the federal armory and arsenal to protect it against any threats until April 1861. While life at Harpers Ferry could not return to the same atmosphere as before John Brown's raid, the production at the armory continued, and during the 1860 census, the town was reliant on the armory as its

\footnotetext{
${ }^{57}$ See Joseph Barry's account of the murder of Colonel Dunn, a superintendent of the armory, by a disgruntled former employee who desired to get his job back. Also the armory employees witnessed turmoil over changes in the pay system from piece work to time-based payment.

${ }^{58}$ See James Lawrence Hooff, The Journals of James Lawrence Hooff, Charlestown, Virginia, now Charles Town, West Virginia, October 7, 1859-June 1, 1864.
} 
economic foundation. The first threat against the armory had shaken the town, but it did not destroy the structure of households in Harpers Ferry. Instead, the town briefly recovered from the shock of John Brown's raid. It was not until April 18, 1861 that the town and their gun-making households were struck by the onset of the Civil War. The households of Harpers Ferry would be particularly impacted by the war because of their marked dependence upon one industry and one factory system for the economic survival of the town. When the Civil War came to Harpers Ferry, their economic foundation was decimated within hours. 


\section{Chapter Two: The Occupied Household}

When Lieutenant Roger Jones and his small contingent of forty US mounted riflemen applied the torch to the gunpowder they had strewn throughout the Harpers Ferry Armory and Arsenal on April 18, 1861, they provided a catalyst that fundamentally changed the household structure of the town. In response, the townspeople, aided by the Virginia militia that had come to seize the instruments of war held within the arsenal, stifled the flames and pulled out the machinery that produced small arms and had defined the town's economy to that point in time. They managed to save the majority of the machines and a small portion of the uncompleted muskets and rifles stored on the premise, but Lieutenant Jones managed to destroy almost two million dollars in the federal government's investment in the industry of Harpers Ferry. ${ }^{59}$

For a town immersed in manufacturing, there lay symbolism in this retrieval of the machinery from fire. On a superficial level, fire was not an uncommon event in towns and cities in the United States at that time. Therefore, the townspeople can be seen as responding to a danger that they understood and could minimize. The existence of the fire engine house, in which John Brown and his raiders had barricaded themselves and their hostages in 1859, points to an acknowledgment of the danger of fire in an industrialized town. However, the fire occurred on the same day as the townspeople learning of Virginia's secession from Alfred Barbour, the superintendent of the armory who represented the town as a Unionist at the secession convention. Townspeople greeted this news with a "partial riot," according to the local historian, Joseph Barry ${ }^{60}$ In light of their angered reaction to secession, the recovery of the armory's

\footnotetext{
${ }^{59}$ O.R., vol 2, Report of Lieut. Col. William Maynadier, U.S. Ordnance Department, of the expenditures upon and losses at the armory, 5-6. This figure includes the purchase of land by the federal government, the improvements upon that land, such as canals for waterpower, and the value of the machinery and firearms stored there in April 1861.

${ }^{60}$ Josephus, Jr., The Annals of Harper's Ferry with Sketches of its Founder, and Many Prominent Characters Connected with its History, Anecdotes, \&c..., 2nd ed. (Martinsburg, WV: The Berkeley Union, 1872), 61.
} 
machinery meant more than simply fire management, but rather an attempt to save the foundation of their town and lives.

This preservation attempt reached further than mere economics, however. As the foundation of the town's economy, the armory provided employment to over 200 men in the town. In attempting to save their jobs, these men also worked to preserve their social system on the night of April 18. Their social system depended on both the subjugation of African Americans, free and enslaved, and the subordination of women and children within the southern household. By attempting to preserve their town's economy, these men also were attempting to preserve their society's masculine dominance over those deemed dependent and their role as the head of household.

According to historian Donald B. Webster, Jr., Harpers Ferry's "heart and soul died on the night of April 18, 1861" and "never recovered." ${ }^{\text {61 }}$ However, while the manufacturing industry, which the armory and arsenal symbolized in the antebellum period, has vanished, the town has survived to the current day. What, therefore, died on the night of April 18, 1861 ? Armory workers continued to lobby for the continued presence of the machinery in the town, and they assembled the firearm parts that survived the blaze. This continued presence of the armory work after April 18 does not mean that life did not fundamentally change that night. For the townspeople, the first occupation during the war began the next day and restructured the very notion of the southern household in Harpers Ferry.

Military troops came to define the wartime experience of the town for the residents. The alternating presence of both militaries brought strict rules of occupation throughout the duration of the war. The previous strength of the institution of the household cracked under the strain of

\footnotetext{
${ }^{61}$ Donald B. Webster, Jr., “The Last Days of Harpers Ferry Armory,” Civil War History 5, no. 1 (1959): 44.
} 
the new daily experiences of military life. Occupation destabilized men's authority in the household, and the military began to assume that role. In essence, occupation changed the role of men in Harpers Ferry and forced them to assume the feminine role of dependency. This feminization of the townspeople played on the issues of independence and dependence based upon the idea of power relations within the southern household. As soldiers undermined the traditional masculine authority over dependents, they asserted their position as the new heads of the occupied households.

Relations between soldiers and civilians form a vital part of occupation during the Civil War, but historians have written about this story typically through the lens of elite white women of the South. The dynamics of these interactions have boiled down to a gendered story of male soldier either harassing a female civilian or a female civilian seeking out favors based on her gender and class. In these studies, the upper-class women were shielded by their conception of gender from soldiers' violations and secure their safety. Both the North and the South held "ladyhood" in a similar regard, and therefore, the elite white women were never in covert danger from occupying troops. ${ }^{62}$ Another study reasserts that women used their gender as a mechanism to "capitalize on the Yankees' ambivalence toward them" by posing as utterly helpless. The “feminine survival strategies" included "coquetry and flattery, feigned stupidity or innocence, and...maneuvering the Yankees into a situation where they would have to use physical force."63 These studies fail to problematize gender. Instead, while they appear to concede that gender was being socially constructed in these interactions between women and male soldiers, the historians

\footnotetext{
${ }^{62}$ Drew Gilpin Faust, Mothers of Invention: Women of the Slaveholding South in the American Civil War (Chapel Hill: University of North Carolina Press, 1996), 198-201.

${ }^{63}$ Stephen V. Ash, When the Yankees Came: Conflict and Chaos in the Occupied South, 1861-1865 (Chapel Hill: University of North Carolina Press, 1995), 71.
} 
take for granted that these gender constructs were fixed and the historical actors were merely playing their role in gender relations. Women acted feminine, and soldiers were masculine.

The gender roles which historians have used to characterize the trauma and strategies of occupation are largely dependent upon the antebellum notion of a household and the role of upper-class women within their households. This concept of a household morphed throughout the Civil War, and gender roles adapted with it. As this process took place, it becomes increasingly important to detach biological sex from gender roles. In her essay "The Civil War as a Crisis in Gender," LeeAnn Whites argues that the conflict sometimes destabilized gender roles and identities in the Confederacy. Confederate soldiers, when facing the various hardships of war, increasingly became aware of their dependence on their women's labor and the relationship between his own manhood and independence and his wife's dependence. Confederate men were forced to acknowledge their own dependence upon women as women became more independent and masculine while they "became increasingly feminized." ${ }^{64}$ In Whites's description, the external factors of separation and warfare exacerbated the internal contradictions within the southern household. However, the internal conditions and dependence among family members were not the only factors that contributed to the destabilization of the household structure.

External factors also took their toll on gender roles and the hierarchies of the southern household. Adding to this transformation were the occupying military troops, who inserted themselves into the internal dynamics of the household and its gender roles. By removing power from independent white men, militaries served as a catalyst for the destabilization of the household. While the internal factors as described by Whites cannot be dissociated from the story of changing gender relations, the significance of occupation on both male and female

\footnotetext{
${ }^{64}$ LeeAnn Whites, Gender Matters: Civil War, Reconstruction, and the Making of the New South (New York: Palgrave MacMillian, 2005), 21.
} 
civilians provides another example of how the Civil War helped to feminize men by removing them as the sole authority over the household.

The household structure of the town weakened almost immediately after Virginia declared its secession and warfare erupted. On a fundamental level, occupation brought an element of the unknown to the town. The uncertainty of troop movement and when armies would evacuate or return permeated through the town. The lack of security and safety for the townspeople exposed the vulnerable nature of the household under conditions of occupation, and as Harpers Ferry moved through the three nebulous "worlds" of occupation, this vulnerability would fluctuate as well. The gender identity of the townspeople, as defined by the power relations of independent man and dependent woman, faced challenges from the enlistment, death, or relocation of men and women and frequent evacuations and reoccupation from both the Union and Confederate armies.

For Harpers Ferry, located on the Potomac River and the border between Confederate Virginia and Unionist Maryland, occupation was not defined by a consistent presence of Union troops as was seen in other regions of the Confederacy. Rather, the town would shift through what Stephen V. Ash describes as the three "worlds" of occupation. Ash argues that the three distinct spheres of Union occupation—garrisoned towns, the Confederate frontier, and no-man'sland - created a distinctive geography of occupation. Garrisoned towns were sites of consistent Union presence and authority where citizens frequently came into contact with the occupiers. In the Confederate frontier, the Union troops only made slight penetration, and citizens were typically within the rule of the Confederacy. In between these two distinct regions, there existed no-man's-land in which Confederate rule or Union rule did not extend. However, the changing 
nature of war caused frequent reclassifications of the status of Confederate regions. ${ }^{65}$ Harpers Ferry moved through these different distinctions frequently during the four years of war, and individual and household safety depended upon the loyalty of individuals and of the strength of their remaining households.

The primary cause of the destabilization of the household was the absence of men. As a social and political unit, the household was defined by the authority of men to represent their dependents. However, once the war came to Virginia, the enlistment, relocation, and death of men caused uncertainty for the households which they left. The first wave of relocation occurred after the burning of the armory on April 18, 1861. Historian Merrit Roe Smith concludes his study of the technological advances achieved at the Harpers Ferry armory by stating that the destruction led many former armorers to seek employment elsewhere. According to Smith, the majority of the armorers followed the machinery and found employment at the Richmond armory, where as many as four out of five shop foremen had been employed at Harpers Ferry previously. The superintendent of the armory also relocated to Richmond. Other workers headed to other armories in both the Confederacy and in the United States, particularly the Springfield armory in Massachusetts. ${ }^{66}$

The relocation of the armory's jobs dealt a severe blow to the town's population, but death brought another element of destabilization to the household. The prospect of death, whether through the loss of a man in battle or the untimely loss of a civilian, overwhelmed some citizens in Harpers Ferry. In late 1863, Jennie Chambers, who lived just outside of Harpers Ferry, described the experience of war as defined by "the moan of the many thousands of

\footnotetext{
${ }^{65}$ Ash, 76-77.

${ }^{66}$ Merrit Roe Smith, Harpers Ferry Armory and the New Technology: The Challenge of Change (Ithaca, NY: Cornell University Press, 1977), 321-322.
} 
fatherless children... and in the tears of sorrowing mothers, and bereaved widows." Chambers wrote that she had "stood and watched the murderous fire of the cannon of both armies," which "seemed to echo back nothing but death and death in its most horrible form.." ${ }^{.67}$ For Chambers, it seemed that death came to men, who left behind suffering families. She worried not her own life but for the lives of men. Despite standing near a battle and perhaps being in danger there, the boom of the cannon symbolized the death of soldiers and her former way of life. Indeed, when Chambers discusses the news of victory, she proclaimed that the word only signified "bloodshed, death, and misery to thousands." ${ }^{68}$

While Jennie Chambers dealt on the potential death of other men, other families were forced to deal with the real effects of it. In his history of Harpers Ferry, Joseph Barry recalled a conversation he had with another local man, Frederick Roeder on June 14, 1861. In this conversation, which should not be taken as verbatim and the definitive words spoken, Roeder questions what the next occupation would bring after Confederates had abandoned the town: "Well, we have got rid of that lot and have escaped at least with our lives, but what will the next party that comes do with us?" Barry described Roeder as being in "low spirits" and then cited his words as prophetic. Frederick Roeder was shot on July 4, 1861 by a Union soldier on the Maryland side of the Potomac River and made his way back home "unassisted — for there was scarcely an able-bodied man then at that place. ${ }^{.69}$ John J. Kern, Roeder's son-in-law, later testified during a claim against the United States that Roeder, a strong Unionist, went to see the American flag, which was flying on Maryland Heights, when he was shot and killed. His death left behind seven children, whose mother had died in early 1861. Afterward, the children became

\footnotetext{
${ }^{67}$ Jennie Chambers, October 8, 1863, "Composition on War."

68 Ibid.

${ }^{69}$ Joseph Barry, The Strange Story of Harpers Ferry with Legends of the Surrounding Countryside (Harpers Ferry, WV: Woman's Club of Harpers Ferry District, 1959), 123-5.
} 
part of the refugees who evacuated Harpers Ferry when it was occupied by the Confederate army. ${ }^{70}$

There is little doubt that Roeder's traumatic death changed the fundamental structure of his household. Without the economic or social support of parents, Mary Roeder, not yet out of her teenage years, became responsible for her younger siblings. Until she married John Kern, who assumed the head of their household, they were largely at the mercy of occupying troops. However tinted Joseph Barry's recollections of their conversation to the coming of Roeder's death, the assigned words, as well as Jennie Chambers's, point to a collective anxiety about the death of men and its impact on the household.

Economic relocation and death sapped the town almost immediately of the vital wage labor provided by male factory workers. However, other military motivations caused exoduses from Harpers Ferry. Enlistment, whether voluntary or coerced, drew out more men from already vulnerable economic situations in the household but did not necessarily mean the departure of the men from the area. Local militias in Jefferson County and surrounding countryside had grown rapidly in response to the potential for abolitionist threats like that of the thwarted John Brown. These militias regularly patrolled the area in the antebellum era to enforce curfews but did not significantly depart from their area of residence. However, when the Confederate army subsumed state militias and forced them into a nationalized hierarchy, the militia officers lost control of their movements. The now-Confederate troops joined the greater fight against the Union army and left their localities.

Prominent men in Jefferson County wrote about their concerns for the militia being taken away in October 1861. Andrew Hunter, the lead prosecutor in the trial of John Brown, sent his

\footnotetext{
${ }^{70}$ Claim of the Estate of Frederick Roeder for Restitution from the U.S. Government, September 5, 1902.
} 
concerns about the local population and, in particular, the undefended women of the county to the interim Secretary of War, J. P. Benjamin. Hunter, describing himself as "under a full sense of the diffidence and delicacy which should govern a mere civilian in dealing with such subjects," complained of the incompetent leadership that relocated the local militia to Winchester "under the miserable pretext of drilling them." To Hunter, while the militia drilled unnecessarily, innocent dependents of households were being left to the whim of the marauding enemy who were "plundering, insulting females, and keeping the whole border for miles into the interior in a state of uneasiness and alarm." ${ }^{, 71}$ By petitioning the Secretary of War for a military officer who would preserve the presence of militia troops in Jefferson County, Hunter clearly linked the vulnerability of the county's households to the absence of men. According to Hunter's account, with the strength of militia and the county's men gone, the Union troops felt no restraint in violating the previously private space of the household, which could be seen also as sexual violation of women. The solution to this violation was to appoint a military officer who would see the necessity of stationing the militia that were the heads of the household in the county.

Another local leading man agreed with Hunter's assessment of Jefferson County. Citing instances in Harpers Ferry in particular, James L. Ranson wrote to President Jefferson Davis to change military leadership in the Shenandoah Valley. Ranson describes the situation as federal troops "desecrating our soil, pillaging our defenseless and loyal people, and outraging the sanctity of helpless and loyal families." Ranson described the story of a widow living in the county whose son had recently been shot in friendly fire. She was "awfully outraged," and her house and farm were "left desolate" because her sons were stationed elsewhere and unavailable to protect her from the Union troops. Again, as in Hunter's letter, the ultimate blame for these

\footnotetext{
${ }^{71}$ Andrew Hunter to Hon. J. P. Benjamin, October 5, 1861, in War of the Rebellion Official Records of the Union and Confederate Armies vol. 5, 889-890.
} 
raids lay with the leadership of General Carson, who remained at Winchester with the militia troops. ${ }^{72}$ Ranson's emphasis on the sanctity of families living within the county draws into the concept of the inviolable household in which the independent man held the ultimate authority that was granted by southern society and law. His rejection of General Carson as a suitable officer lay in the fact that Carson seemed not to care about these "outrages" against the families and that his headquarters in Winchester was too distant for the militia troops raised in Jefferson County to protect their families.

A third letter petitioning for a change in military leadership came from A. R. Boteler. Boteler wrote to R. M. T. Hunter, who acted as Secretary of State. In this letter, Boteler describes the situation of Jefferson County as worsening. The county, which acted as the border into the Shenandoah Valley, became "more alarming every day," and according to Boteler, "no night passes without some infamous outrage upon our loyal citizens." Again, the blame is attributed to a too-small Confederate force to protect the citizens, but in addition, Boteler claimed that the "traitors" of Jefferson, Berkeley, and Morgan counties "cannot be controlled or guarded against unless some one be invested with authority to deal with them as they deserve." These spies had been communicating with federal troops and giving them information about the Potomac River and the Chesapeake \& Ohio Railroad. Boteler, however, responded differently than either Hunter or Ranson in his proposed solution to the problems in Jefferson County. He solicited for the promotion of a particular man to take over command of the troops. Boteler claimed that some militia troops would refuse to fight under anybody but Turner Ashby, who should be promoted to a full colonel. ${ }^{73}$

\footnotetext{
72 James L. Ranson to Jefferson Davis, October 15, 1861, in O.R. 5, 898-899.

${ }^{73}$ A. R. Boteler to Hon. R. M. T. Hunter, October 24, 1861, in O.R. 5, 919-920.
} 
All three of these letters follow a similar format and were written by prominent men in the county to prominent men in the Confederate government. These letters were written exclusively in October 1861. There is a clear local strategy displayed in these letters. By widening their audience to three men high in the Confederate administration, Hunter, Ranson, and Boteler petitioned for the return of the militia troops to Jefferson County. In addition, they all emphasize the effect that troops' departure had on the household. Hunter, Ranson, and Boteler seem to write as advocates for the "helpless families" vulnerable to Union troops, but they also reveal their own vulnerabilities. When the militia left, these prominent men were also left without protection. Their solution is then to prostrate themselves before the Confederate government to restore the social order embodied within the antebellum household and to repulse the Union troops from having any power over them.

In these letters, the three prominent men of Jefferson County show the impact of the Union occupation of Harpers Ferry not just on women but also on themselves. By writing to Confederate government officials, they acknowledged their own loss of independence and the loss of any man's independence in the county. Instead of accepting the dependency that was forced upon the civilians by federal troops, they submitted themselves to dependency on the Confederate government to receive protection. Without the renewed presence of the county's militias, they could not occupy the same position as they had in antebellum times. War had made them dependent and therefore less masculine.

However concerning the presence of Union troops and the lack of their county's militias was to Andrew Hunter, James Ranson, and A. R. Boteler, the feminization of occupation can be seen in more than just desperate letters to Confederate government officials. The southern household and its apparent sanctity was formed in part by spatial considerations of where men's 
authority was held to be absolute. Therefore, when Union troops entered the physical space of the household, they were delegitimizing the former master's authority and asserting themselves as the rightful authority and master. Whether they entered to strip doorknobs or objects from the house or to find a suitable place to sleep, these soldiers wreaked havoc on the southern conception of their society.

The space of the household informed the amount of power that the head of household could derive from his command over dependents. Stephanie McCurry discusses the spatial element to the power of the household by analyzing the importance of fences to yeoman farmers and southern society in South Carolina. The fence gave a legal definition as to what constituted an enclosure and therefore a household. The act of placing a fence around a man's property defined it as an "inviolable private space," which legitimized the master's power as absolute. ${ }^{74}$ In low-country South Carolina's yeoman households, then the fence became a meaningful symbol of power and warned other masters of the owner's legal right to what lay within his enclosure. By defining the space in which his power was absolute, the master was, in fact, legally justifying any coercive or violent behavior toward his dependents.

The social structure of Harpers Ferry, however, differed significantly from the lowcountry of McCurry's study. Harpers Ferry, with its decided lack of commercial agriculture and reliance on manufacturing, did not function spatially like South Carolina with its extensive plantations and agricultural households. Therefore, fencing did not play as significant a role in the social formation of households. However, the difference in economy between the two places does not invalidate McCurry's argument about the legal need to define the boundaries of men's power in the space of the household. Instead of an enclosure bound by fences on all sides, the

\footnotetext{
${ }^{74}$ Stephanie McCurry, Masters of Small Worlds: Yeoman Households, Gender Relations, and the Political Culture of the Antebellum South Carolina Low Country (New York: Oxford University Press, 1995), 11.
} 
physical space of the residence and the symbol of the house can fill the need for legitimacy of power. In the town setting, doors and windows formed the private space of the household.

The military assault on the privacy of Harpers Ferry households came with the destruction of the armory and the resulting occupation by Confederate troops in April 1861 . Joseph Barry noted how quickly the town became a military base. The residences provided by the federal government for the armory workers were quickly seized, and the families renting them were forced to vacate the residences. ${ }^{75}$ The seizure of these houses can be seen as a direct affront to any local sentiment that might still exist within the town toward the federal government and also as a way to destabilize the households that might have resisted Confederate occupation. On a deeper and more symbolic level, however, the seizure represented the violation of the household and therefore the destruction of antebellum independence. Instead, by forcing perhaps long-term residents out of their houses, it asserted the civilians' dependence upon the military and the military's refusal to acknowledge their independence and property rights as defined by southern society.

The widespread seizure of residences for the military's use was not the only way in which both militaries symbolically destroyed the household in Harpers Ferry. The act of taking door locks, windows, and other fundamental elements of a house also represented the same concept of making civilians dependent. Annie Marmion, who was a young girl during the war, described the vacancy of the town by asking her reader to "Imagine a Town filled with house[s] enough to accommodate over 2,000 people and more than nine tenths of them empty...not a door in all these houses had locks or bolts of any kind." She emphasized the loneliness of the town that was broken by the sound of doors slamming. ${ }^{76}$ George Wood Wingate, in his regimental

\footnotetext{
${ }^{75}$ Josephus, Jr., 64.

${ }^{76}$ Annie Marmion, Under Fire: An Experience in the Civil War, ed. William Vincent Marmion, Jr. (1959), 6.
} 
history of the $22^{\text {nd }}$ New York National Guard, referenced the same barrenness of Harpers Ferry. According to these post-war recollections, the vacant houses were so numerous that soldiers tore two down and used the wood from twelve houses for campfires. In addition, soldiers removed the doors from houses to use as beds. ${ }^{77}$ Another man, who lived in Bolivar, went to an officer in the $34^{\text {th }}$ Massachusetts Infantry to charge that soldiers in the regiment had stolen the doors and windows from his brother's house in 1863. The officer, however, refused to believe that his men had committed such an action and claimed that instead of his troops from Massachusetts, the real thieves were either convicts or troops from another unit. Needless to say, after the man could not identify definitively the place of origin of the troops besides his impression of their accent, his complaint was ignored, and the officer warned him against attempting to defame soldiers again. ${ }^{78}$

These incidents of theft by soldiers represented a clear disregard of the property rights and of the concept of household authority belonging to independent men. The image of empty houses with either constantly slamming doors or with the distinctive lack of doors and windows brings to mind the utter desolation and the lack of recourse available to the remaining citizens of Harpers Ferry. Without any reliable recourse, the civilians were left to accept the authority of the military troops in the town. As such, their wartime situation, regardless of their biological sex, resembled that of the antebellum dependent, who also lacked the legal recourse to change their subordinate status. Unable to protect the physical space of their household and the physical elements that had rendered it private and secure from intrusion, all civilians were rendered dependent on the armed men who occupied their town.

\footnotetext{
${ }^{77}$ George Wood Wingate, History of the Twenty-second Regiment of the National Guard of the State of New York: From its Organization to 1895 (New York: Edwin W. Dayton, 1896), 61-62.

${ }^{78}$ William S. Lincoln, Life with the Thirty-Fourth Mass. Infantry in the War of the Rebellion (Worchester: Press of Noyes, Snow \& Company, 1879), 131-132.
} 
The pressure on the household increased with the military necessity of finding place in Harpers Ferry for, at times, thousands of troops. In a town designed for approximately 2,000 to 3,000 residents, the substantial increase in population put more strain on the household.

However, troops were not alone when they garrisoned a town. Significantly more contrabands, or runaway slaves seeking safety and protection within Union lines, swelled the overpopulation and represented far more than the antebellum black population of the town. In this crowded situation, adequate housing became a premium and therefore a source of contention between occupying troops, white townspeople, and African American refugees.

The first Confederate occupation of the town in early 1861 began the conversation about the occupation of private residences from the onset of the war. In May 1861, George Deas, the Inspector-General of the Confederate Army, reported that the majority of the Virginia militia troops stationed at Harpers Ferry were being quartered in the houses of Harpers Ferry and Bolivar. The reason he cites for this large portion is that the Virginia troops were "only partially supplied with tents." ${ }^{79}$ For the Confederate army, the necessity lay not in respecting the property of the civilians but acquiring adequate housing for soldiers who were guarding the machinery until it was sent to areas out of Union reach. In the beginning, therefore, the quartering of soldiers in the houses of the town was required because of the utter lack of supplies for the Confederate army.

Another military necessity for troops quartering in residences was caused by the movement of troops. When the $22^{\text {nd }}$ New York National Guard were moved from a camp to a closer location to Harpers Ferry, they quartered in houses for a day because their tents and

\footnotetext{
${ }^{79}$ Report of Inspection at Harpers Ferry by Lieut. Col. George Deas, Inspector-General C. S. Army, May 23, 1861, in O.R. $2,868-870$.
} 
equipment had not been moved with them and lagged behind. ${ }^{80}$ In this circumstance, the quartering was merely temporary until the soldiers' equipment arrived. Temporary or not, the effect of the military seizure of residences reinforced the uncertainty of war and the helplessness of civilians to prevent their houses from turning into barracks.

Not all seizures were for military necessity, though. Some soldiers seemed to take pleasure in quartering either their families or their livestock in the residences of Harpers Ferry. William Lincoln, in his regimental history of the $34^{\text {th }}$ Massachusetts Infantry, recalls that many officers brought their wives to Harpers Ferry. For appropriate lodging for them, the military evicted other temporary residents of the houses, who Lincoln claimed had "no more right than our own men. ${ }^{181}$ Whether the previous occupants had been contraband, white refugees, or perhaps civilians of the town, Lincoln's dismissal of any claim other than that of the military points to his perception that the military was, in fact, master of any house and therefore household in the town. In addition, he conflated the rights of soldiers to quarter in residences with the right of their wives to do so as well. For William Lincoln, the emotional needs of the federal soldiers outweighed any distress of dislocation on the part of the civilians of Harpers Ferry. In this mindset, the northern family mattered more than the property rights of southern families.

In another instance, William Lincoln seems to take particular pleasure in restructuring the southern household. As officers were plenty in Harpers Ferry, so then were horses. Lincoln wrote in his history of the $34^{\text {th }}$ Massachusetts that in September 1863, the regiment had begun to prepare their quarters for the upcoming winter. Instead of relocating to the residences in town themselves for the winter, the soldiers moved twenty horses into "the basement of what was one

\footnotetext{
${ }^{80}$ Wingate, 61-62.

${ }^{81}$ Lincoln, 125.
} 
of the most expensive and elegantly furnished houses in the village. ${ }^{.82}$ This residence probably belonged to a rich and prominent man in the community; therefore, with his wealth, he would have felt the power of southern society through his command of household dependents. The loss of his house to horses signified a significant change in the power dynamics of masculine and feminine, independent and dependent, occupier and occupied.

The removal of key objects in the house could not compare to the quartering of troops in a family's former or current home. The destabilization of household was completed when troops seized houses to rest for a few nights or to occupy indefinitely. More than simply removing objects from a residence, quartering troops definitively changed the authority and mastery over the household to the occupiers. By boarding in residences, the military usurped the authority of the southern independent man and commanded dependency and deference from all civilians.

With the white southern men's power thus usurped, the military forces that entered Harper's Ferry asserted their authority through occupation policies that took further independence away from the civilians that remained in the area. These policies removed privileges and powers previously reserved for independent whites. The prerogatives of whiteness and, in particular, white manhood ceased to secure them the distinctions that they had held through the antebellum period over free blacks, slave, and white women. As their independence was eroded by occupation policies and white men symbolically became one of the dependents within the occupied household, they found themselves on the same level as those whom they had degraded.

As contraband laborers and runaway slaves flooded into the town, the townspeople were powerless to exert their previous authority over blacks. The white residents were forced to cleave

${ }^{82}$ Ibid., 133. 
to the military policy about contraband of war, whether it was the federal troops who protected these people within their lines and put them to work or the Confederate soldiers who seized them for resale in the Shenandoah Valley. As the townspeople found themselves like contraband laborers and runaway slaves in the position of forced dependency, they could not exert the same control over those considered property by the local and state governments of Virginia.

During the times of federal occupation, there existed two distinct groups of black civilians within Harpers Ferry. To distinguish between the different precarious situations and statuses, I plan to use two different terms to describe "contraband" more specifically. The first term, runaway slave, refers to those who came into Harpers Ferry from nearby areas to escape their enslavement there. These runaway slaves could be subject to reclamation by their master or mistress if the slaveholder pursued them into the garrisoned town. The second term, contraband laborer, refers to those who were brought into the town by federal troops from larger cities like Washington, D.C. where there was much larger concentrations of contraband slaves. The contemporaries during the Civil War did not distinguish between the two groups and used the common term "contraband" to refer to both. However, these two terms expose the gradients of freedom in Harpers Ferry and attempt to avoid conflating the two situations of enslaved or formerly enslaved African-Americans in the town.

In 1862, when the federal troops first consistently occupied the town of Harpers Ferry, the runaway slaves in the town increased dramatically. George Wood Wingate, as the author of the regimental history of the $22^{\text {nd }}$ New York Regiment, claimed that in the summer of 1862 , there were 5000 contraband laborers and runaway slaves in Harpers Ferry. The soldiers in the $22^{\text {nd }}$ New York allowed runaways within their lines because they pitied the "poor bedraggled, foot-sore wretches" who appeared in "the gray of the morning, having walked ten or fifteen 
miles during the night, seeking the protection of the Union lines." Wingate claims that the runaway slaves entering the town were frequently women with multiple children. These families then "crowded the empty houses, and overran the camp." However, because these runaways were willing to do various jobs for food or small amounts of money, the regiment used them to wash clothing and cook for them. ${ }^{83}$ In Wingate's recollection, the soldiers' attitude toward these runaway slaves was paternalistic and a clear indication that they filled similar work roles that slaves had for the southern households before the beginning of the war. For soldiers, the conveniences that the slaves brought to their camp, whether in the form of pastries or berries or clean clothes, relied on the slaves' dependence on federal protection and overall federal policy toward them.

When these runaway slaves departed from nearby plantations and farms and went to Harpers Ferry, their owners could not appeal to the federal troops to have them returned. Rather, their property could only be returned when Confederate troops had captured the town. In March 1862, Amelia Beckham Hooff woke to discover that her slaves had left her farm outside of Charles Town, roughly six miles from Harpers Ferry. She wrote in her husband's ledger that "every woman \& child" was gone, along with her wagon and some of her property, and that her home "looks deserted." Later in the week, a male neighbor went to Harpers Ferry to learn the location of Hooff's slaves. On March 17, 1862, one of her remaining slaves, George, talked to the slaves at Harpers Ferry and learned that "they were not willing to come back." ${ }^{\circ 4}$ Hooff's situation reflects the authority of the federal troops when they were occupying Harpers Ferry. Clearly, there is no established return mechanism for Hooff's slaves or the return of her property

\footnotetext{
${ }^{83}$ Wingate, $84-86$.

${ }^{84}$ Amelia Beckham Hooff, The Journals of James Lawrence Hooff, Charlestown, Virginia, now Charles Town, West Virginia, October 7, 1859-June 1, 1864, 121. Most entries were written by James Lawrence Hooff, but when he joined the Confederate army, Amelia began to record events in his ledger.
} 
that was taken by the runaway slaves. Instead, the runaway slaves can say that they will not return to their mistress's authority but have the ability through the federal troops' authority to refuse. Without the approval of the military, Hooff or her male neighbor had no recourse as the troops were the ultimate authority in Jefferson County. This circumstance clearly shows the decreased status of Amelia Hooff and the increased status of runaway slaves in Harpers Ferry and thus put them on the same level of dependence to federal troops.

The second group of contraband came to Harpers Ferry through direct military orders. During the summer and fall of 1862, contraband laborers were sent to the town to help fortify it against Confederate attack. The entrenchments that the laborers constructed were considered by federal officers to be vital components in being able to successfully hold Harpers Ferry against enemy attacks. In June 1862, Major-General John E. Wool ordered Colonel Dixon Miles to build entrenchments on Camp Hill. The order stated that if the soldiers under Miles's command would not be able to perform the labor, Miles was authorized to "employ contrabands for the purpose." ${ }^{85}$ Wingate described the breastworks as a line which "extended along the top of the hill from the bluffs overhanging the Shenandoah, about 350 yards towards the Potomac" and constructed "all summer by gangs of negroes." ${ }^{86}$ While neither Wool nor Wingate confirm the origins of these laborers, their employment in these entrenchments differentiates them from the runaway slaves who worked as cooks for individual soldiers and points to a more formal relationship with the federal troops.

This formal relationship between contraband laborers and the federal government was more prominent in the fall of 1862. After the disastrous surrender of Colonel Miles at Harpers Ferry, General George McClellan blamed the blame for his loss on his lack of fortifications on

\footnotetext{
${ }^{85}$ Special Orders, No. 7, June 15, 1862 in O.R., vol. 19, part 1, 788.

${ }^{86}$ Wingate, 111.
} 
Maryland Heights and Loudon Heights. McClellan's solution is to fortify the town much more to prevent another surrender of the town. In September 1862, just after the battle of Antietam, McClellan sent a request to General-in-Chief Halleck for contraband laborers to be sent from Washington D.C. to build these fortifications. McClellan then makes a requisition for 2,000 contraband laborers from the military governor of Washington, D.C., which is reinforced by an order by the Secretary of War to fill the need for laborers at Harpers Ferry ${ }^{87}$ McClellan's order clearly distinguishes the two types of African Americans living in Harpers Ferry during the fall of 1862 . The contraband laborers were a mobile work force directly linked with the Union war effort, while the runaway slaves sought their freedom within Union lines sporadically. Moreover, contraband laborers were likely to be paid directly from the federal government, whereas in Wingate's description of their labor in Harpers Ferry as servants to individual soldiers or to a mess, these runaway slaves were paid out of individual soldiers' pockets.

It is unknown how many of Wingate's estimation of 5,000 former slaves were contraband laborers or runaway slaves in the summer and fall of 1862 , but both groups were in a precarious status when Colonel Dixon Miles surrendered Harpers Ferry on September 15, 1862 to General Jackson and General A.P. Hill. When reporting the operations of his brigade, one Confederate Major commented that the garrison surrendered "to the delight of the soldiers and to the disgust of the contrabands.. ${ }^{, 88}$ Those 5,000 African Americans dependent on federal troops for their protection and for their labor were then subject to the will of the Confederate Army as the terms of surrender did not include any provisions for them.

\footnotetext{
${ }^{87}$ O.R., vol. 19, part 2, 360-2, 366.

${ }^{88}$ Report of Major H. J. Williams, Fifth Virginia Infantry, commanding Winder's brigade, of operations September 1-19 in O.R. vol. 19, part 1, 1011.
} 
After the surrender, runaway slaves that had come to Harpers Ferry for freedom were sent back to their former masters or resold into slavery by the conquering Confederate troops. Anne Madison Willis Ambler wrote in early September 1862 that all the slaves had deserted her father's plantation, Rock Hall, near Summit Point, Virginia in Jefferson County. After September 15, 1862, many of her neighbors went into Harpers Ferry to reclaim their slaves from there, but Anne's father did not go. Just two days later, a Mr. Flagg brought back the runaway slaves from the town. ${ }^{89}$ Later in the war, Annie Marmion described a similar reclamation: "a sudden and rapid advance of the Confederates had sent the Contrabands running for their lives and freedom far in advance of the Northerners, for they well knew that their Masters would follow the Confederates to reclaim them." 90

However, some federal troops attempted to prevent this reclamation of African Americans into slavery. The commanding officer of the Sixtieth Ohio Regiment, Colonel William H. Trimble, went to significant lengths to provide that the thirteen free blacks, who had accompanied the regiment from Ohio, would be allowed to leave Harpers Ferry. After the surrender, Trimble sought out Jackson on their behalf and was referred to A. P. Hill. The regimental history quotes A. P. Hill as saying, "As great numbers had fled from the surrounding country to Harper's Ferry, it would be difficult to decide who was free and who was not; he would, therefore, leave it to the Colonel's honor, and give him passes for whoever he said was free." After obtaining passes for the thirteen black men from Ohio, the regiment was halted by other Confederate soldiers. The Confederate major told Colonel Trimble that he was a "d---d nigger thief, stealing their slaves, and his command shouldn't pass till every d---d nigger was taken out." In order to pass through the Confederate lines, Colonel Trimble was quoted as

\footnotetext{
${ }^{89}$ September 4, 1862 through September 17, 1862, diary of Anne Madison Willis Ambler.

${ }^{90}$ Marmion, 9.
} 
threatening the Confederate soldiers and saying, "My men are unarmed-I am not. I'll sell my life for these free boys." These words ensured that the free Ohioans reached the Maryland side of the Potomac River. ${ }^{91}$

Colonel Trimble's attempt to save the Ohioan free blacks in Harpers Ferry brought up the question of authority in transition. Significantly, the colonel did not attempt to stop the runaway slaves or contraband laborers from being reenslaved but rather the free black men that had travelled with their regiment. His words, although perhaps changed in the postwar publication of the history, suggest that he was willing to die for those whom he considers dependent upon him but not the other African Americans who faced similar consequences. In the story, Colonel Trimble did not dispute that the contraband within Harpers Ferry were then under the authority of the Confederate troops. Instead, Trimble saved 13 out of potentially 5,000 African Americans who were affected by the surrender of the garrison and left the rest to the Confederate officer's will. While Trimble's actions could be construed as a resignation toward the enslavement of the contraband or even as a lack of desire to save the other contraband, it is clear by both Trimble and the Confederates' actions that Trimble's authority as head of household only extended to the fate of the thirteen free blacks and no further.

Instead, the Confederate major and soldiers in this account seized what they considered to be their legitimate dependents after the surrender. Assuming that any African Americans were runaway slaves, they called Trimble a "nigger thief" who stole "their" slaves. The meaning of "their slaves" can be disputed whether the Confederate soldiers refer to the South's slaves in general that the Union troops had been protecting within their lines or specifically the runaway

\footnotetext{
${ }^{91}$ Whitelaw Reid, Ohio in the War, Her Statesmen, Generals, and Soldiers: Volume II: The History of Her Regiments and Other Military Organizations, first published in 1867 (Cincinnati, OH: The Robert Clarke Company, 1895), 359-360.
} 
slaves in Harpers Ferry. For whichever case, the Confederate soldiers accused federal troops of violating their conception of the southern household by allowing slaves to stay within the town. Trimble, in response, only attempted to leave with free African Americans and not any of the runaway slaves who could be from a southern household.

As the authority in Harpers Ferry shifted from Union officers to Confederate officers, the Confederates attempted to restore their idea of the household. George Wood Wingate describes the reclamation of runaway slaves through the recollection of other soldiers who were left behind hospitalized after the surrender: "all these poor creatures were taken from their houses, formed into a great drove, and driven South, like so many cattle, crying and wailing for their lost glimpse of freedom, and presenting a heart-rending spectacle as they were marched down the [Shenandoah] valley." 92 The Confederates reasserted their authority and power in Harpers Ferry by "driving" runaway slaves south like chattel and reinforced their idea that southern men were the legitimate heads of household in the town. However, the Confederate control of the town and of the dependents within it only lasted a brief time. Less than two weeks later, McClellan ordered 2,000 contraband laborers to be sent from Washington to prevent another surrender.

After the capture of Harpers Ferry in September 1862, federal troops held the town for the remainder of the war. David Hunter Strother, a native of Jefferson County and an officer in the Union army, crossed the pontoon bridge into Harpers Ferry in February 1862 and described the destruction of Harpers Ferry: "The appearance of ruin by war and fire was awful. Charred ruins were all that remain of the splendid public works, arsenals, workshops and railroads, stores, hotels, and dwelling houses all mingled in one common destruction." ${ }^{, 93}$ Two years later, when

\footnotetext{
92 Wingate, 84-86.

${ }^{93}$ David Hunter Strother and Cecil D. Eby, A Virginia Yankee in the Civil War: The Diaries of David Hunter Strother (Chapel Hill: University of North Carolina Press, 1998), 4.
} 
Strother returned once again to Harpers Ferry, his conclusion was little different: "Harpers Ferry gutted and desolate. ${ }^{, 94}$ For Jennie Chambers, the effect of the war was destruction and demoralization. In 1863, she described Virginia as "those once beautiful hills, and valleys which formerly were in a state of cultivation, but have now all been laid waste." If one saw them, she wrote, "one could hardly imagine that they had ever been anything else but one barren desert." Both of these writers describe the devastation of the local economy as indicative of the wartime destruction in Harpers Ferry. Strother's reflection on the charred remains of the armory and the destruction of businesses demonstrates the importance of those places to his idea of what Harpers Ferry once was. Jennie Chambers, whose father was a farmer, instead points to the lack of cultivation in her description of the barren desert surrounding Harpers Ferry. The death of the gunmaking industry in the town led to far-reaching consequences for the residents.

The town became militarized and revolved around the movement of troops. When Charles Moulton arrived in the town in July 1863, he described it as a "once lovely region...but now all is desolated and utter ruin... and the entire place is not actually worth $\$ 10$. ." Harpers Ferry looked "deserted and lonely," and as he looked at the town, he saw "a crowd of women and children fleeing into the town from the mountain roads, which shows that the army is evidently not far away." ${ }^{96}$ Even with the desolation of the town and the constant presence of troops, women and children are returning to the town to avoid the Confederate army. The military's feminization of the townspeople did not force every resident to give up on the town. Instead, when the military forced the residents to adapt to its authority as the new head of

\footnotetext{
${ }^{94}$ Ibid., 279.

${ }^{95}$ Chambers, Composition on War, October 8, 1863.

${ }^{96}$ Charles H. Moulton, Fort Lyon to Harper's Ferry: On the Border of North and South with "Rambling Jour": The Civil War Letters and Newspaper Dispatches of Charles H. Moulton (34 ${ }^{\text {th }}$ Mass. Vol. Inf.), ed. Lee C. Drickamer and Karen D. Drickamer (Shippensburg, PA: White Mane Publishing Co., Inc, 1987), 122-4.
} 
household, it opened an opportunity for women to assert themselves through their dependency on the military. 


\section{Chapter Three: The Reconstituted Household}

In the spring of 1864 , Charles Moulton wrote of a "most novel instance" that occurred while he was on duty in the Provost Marshal Office in Harpers Ferry. The duty of the provost marshal and his guard routinely included regulating the occupied townspeople of Harpers Ferry. Moulton wrote of the townspeople relying on the military to serve as a judge and jury in numerous disputes and problems, even if Moulton and perhaps the provost marshal, Alonzo Pratt, believed them to be "very laughable incidents." As Moulton described it, this reliance was so severe that "nothing can be done without the Prov[ost] Marshal's sanction" where martial law was in place. According to Moulton, the townspeople sought approval for everyday events, such as getting married or having a dance. Looking from the occupied people's perspective, though, it might have been difficult to determine where the military's authority over their lives ended and which actions were safe from military censorship..$^{97}$

In his letter to his mother dated April 1864, Moulton described the interactions of a young girl, her father, a soldier, and the provost marshal. These four persons became entangled in a situation that best illustrate both the breakdown of the traditional gender structure and the reestablishment of it on the girl's terms. On April 16, 1864, an old man entreated for the provost marshal to stop his daughter from being issued a pass and then leaving on a train with a soldier. About three hours later that same day, the girl in question arrived in the office to obtain permission to go to Pittsburgh, Pennsylvania. The clerk in the office stopped her from leaving the office, and soon the father and her sister arrived back at the Provost Marshal's office to confront the "wayward miss." According to Moulton, when asked why she was attempting to

\footnotetext{
${ }^{97}$ Charles Moulton, Fort Lyon to Harper's Ferry: On the Border of North and South with "Rambling Jour": The Civil War Letters and Newspaper Dispatches of Charles H. Moulton (34th Mass. Vol. Inf.), ed. Lee C. Drickamer and Karen D. Drickamer (Shippensburg, PA: White Mane Publishing Co., Inc., 1987), 179-182.
} 
leave, the girl replied, "Bekase I am used so. I have stood it as long as I shall. You have treated me like a servant ever since mom died and I am going where I shall be used decent. If you take me home, I won't live with you. I will kill myself." ${ }^{98}$

Soon, however, the soldier came in to the office and was questioned by both the Provost Marshal and the girl's father about his intentions. The soldier stated that he intended to take her to Pittsburgh and there pay all her expenses and for an education. After his term in the army had expired, he planned to return and marry her, but when questioned further, it emerged that the soldier did not give the financial ability to support her. Moulton suspected that the soldier actually intended to "gratify his own pleasures in her company" and afterward leave her as a "ruined girl" in Pittsburgh. The officer told the girl to return home to her father and the soldier to leave without her, but contradictory to these suggestions from the officer, the girl and the soldier planned to meet again in two weeks in full hearing of the officer and the father. Moulton reveals the most important detail of this encounter in a dramatic flair in his last few sentences of the story. This young girl, who chose to be potentially ruined by a deceiving soldier rather than remain with her father, was only 12 years old, and her appearance was only that of a "mere child" who had not yet hit the final growth spurt of puberty and was not five feet tall. ${ }^{99}$

Modern reactions to this tale might gravitate to the girl's age or to her threatening suicide, but other, more puzzling questions emerge from Moulton's letter to his mother. If this was the era in which women and children were dependent on their heads of household and a period when the white male ruled unconditionally, how could a prepubescent girl openly defy her father and the military officer charged with policing the town seemingly without repercussions? Indeed, this young girl asserted her own capacity for decision in a town that fell consistently under the

\footnotetext{
${ }^{98}$ Ibid.

${ }^{99}$ Ibid.
} 
shadow of war. Excepting the loss of her mother, the household in which the father and the girl lived had not been fundamentally disrupted by military service or other dislocation of its nominal head. The provost guard existed to control the potentially disloyal occupants of the town. If her father's authority could not have restrained her from eloping with a Union soldier, then the provost marshal should have been sufficiently authoritative to suppress the elopement.

This question of how a young girl assumed the leading role in determining her station lies in both the antebellum gender structure and the destabilization of gender roles in the Civil War. The occupying troops in Harpers Ferry feminized both male and female townspeople. For the occupied men, the troops had taken away their authority within the physical spaces of their households and over their dependents. As the status of male townspeople fell to that of dependents themselves, the occupying troops asserted themselves as the new heads of household in occupied Harpers Ferry during the Civil War. This gender uncertainty allowed local women to assert their own choice to whom they pledged their dependence. By asserting themselves as dependents of the occupying troops, they could then define the extent and limitations of that dependency and of the occupation of the town. Rather than demonstrating the typical use of power to assert a person's independence, this choice represents the fluidity of gender roles during occupation and reflects both the power and powerlessness of women in Harpers Ferry throughout the war. Women were not asserting themselves as autonomous individuals in a protofeminist manner but were rather still bound by their subordinate status in American society. The breakdown in antebellum notions of dependency led women to have new power in the choice of their dependency.

When women chose their dependencies, they more reacted to their changed environments and less asserted their own desire for equal status with men. Historians have studied women's 
changing place in the South during the Civil War and shown how, in some locations, that women became more independent and were forced by the absence of men to enter the previously blocked world of plantation management and economy. ${ }^{100}$ Historians Gregory P. Downs and Stephanie McCurry have also discussed how women, dealing with the absence of men and with the economic devastation in certain regions of the Confederacy, solicited help from Confederate officials and declared themselves as dependents on those men as a result of social hierarchies because the governments promised but had failed to uphold the social contract defined by white men's patriarchal prerogatives. ${ }^{101}$ However, these appeals depended on the continued existence of the hierarchies. Indeed, if there was little structure of state or local governments left, the women within those areas could not work within the system of hierarchical dependency and appeal to the officials above their husbands or fathers within the Confederate army. These hierarchies depended on a society left relatively intact in wartime.

In Harpers Ferry, however, these hierarchies were subsumed by occupying troops. Female townspeople could not easily write to Governor Letcher or to Confederate officials in Richmond and expect substantial results. Instead, the women of Harpers Ferry turned to the authorities who controlled access to the town, which alternatively were both Confederate and Federal occupying troops. When women declared their dependency on the occupying troops, it was not within the assumed social hierarchies or even based on their loyalty. Instead, asserting themselves as dependents served women to align themselves with the more powerful group, but it did not mean that these women committed themselves indefinitely to the cause of the

\footnotetext{
${ }^{100}$ Drew Gilpin Faust, Mothers of Invention: Women of the Slaveholding South in the American Civil War (Chapel Hill: University of North Carolina Press, 1996). Victoria E. Ott, Confederate Daughters: Coming of Age during the Civil War (Carbondale, IL: Southern Illinois University Press, 2008).

${ }^{101}$ Gregory P. Downs, Declarations of Dependence: The Long Reconstruction of Popular Politics in the South, 1861-1908 (Chapel Hill: The University of North Carolina Press, 2011). Stephanie McCurry, Confederate Reckoning: Power and Politics in the Civil War South (Cambridge, MA: Harvard University Press, 2010).
} 
Confederacy or of the Union. Rather than committing themselves to those troops who matched the female townspeople's political ideology, the presence and persistence of occupying troops meant that occupied dependency relied on accommodation of which army was in the town. In this sense, female townspeople's flexibility with both their perceived loyalty and with their dependencies helped them to weather the storm of occupation and to shape the occupation of Harpers Ferry.

Occupation was a collaborative process between the occupiers and occupied. The military officials and troops governing occupied territory did not have definitive regulations and expectations at the beginning of the war. They entered into the war without a clear system of occupation, but as the war progressed through four years of conflict, governing systems developed in response from the Federal and Confederate governments and from the military officials dealing with the logistics of opposition. This give-and-take allowed for the strategies of occupation to develop as required by local necessity. Therefore, as the military necessities shifted, the rules of occupation changed as well. Equally important to the changes in the war, the personality and the concerns of key military officials on the ground also changed those rules of occupation. The severity of confiscation and of onerous regulations for civilians depended in large part on the military officer placed in charge of a given area. As a result, the occupied citizens and, in particular, the occupied women played a direct role in how occupation operated. ${ }^{102}$

Given the large-scale efforts of attempting to regulate the civilian populations of the South, the military officials on the ground were in part responsible for their own jurisdictions

\footnotetext{
${ }^{102}$ William A. Blair, With Malice Toward Some: Treason and Loyalty in the Civil War Era (Chapel Hill: University of North Carolina Press, 2014), 130-137. LeeAnn Whites and Alecia P. Long, introduction to Occupied Women: Gender, Military Occupation, and the American Civil War (Baton Rouge: Louisiana State University Press, 2012), 1-13.
} 
without official commands coming from Washington. Therefore, in this grey area of military occupation and its relative severities, the day-to-day interactions of occupying troops and female townspeople served as a negotiation between military regulations and the residents' needs and desires that had been stifled by economic destruction in the town. As female townspeople grew to know their occupiers and sought their favor by committing their loyalties and their energies to supporting the Union troops within Harpers Ferry, the military officials could be swayed into being more lenient toward those whom they considered to be patriotic. These military officials were then adopted into household networks through the reorientation of the town's economy during the Civil War.

The first step in developing the household network between military officials and the dependent townspeople was through reestablishing the town's economy around the needs of the armies. This reorientation revolved around making the soldiers more comfortable in the occupied town and providing services and goods that were not supplied by the federal army. Harpers Ferry's economy was destroyed early with the destruction of the U.S. armory, which served as the source of employment for most of the town. Afterward, the occupying forces opened an opportunity for the townspeople to build up a service economy around their presence. These new sources of employment were based on the service industries that had thrived in Harpers Ferry before the war began, but without the armory and other factories, food vendors, tavern keepers, and boardinghouse keepers became central to the economy of the occupied town.

Beginning shortly after the destruction of the federal armory, the town was flooded with Confederate troops. Local historian Joseph Barry wrote that this first occupation in April 1861 had totally destroyed "regular business" but new businesses flourished in the town. In particular, he mentioned that the "new branches of industries" in baking pies for soldiers and smuggling 
whiskey commenced in early 1861 and then continued throughout the entire war. ${ }^{103}$ While Barry did cite a number of violent episodes targeted at Unionist townspeople, the town, which had voted to remain in the Union, was relatively free of backlash from Confederate troops or Confederate sympathizing townspeople. Baking pies for the Confederate soldiers that occupied the town was both a combination of preserving the peace and reestablishing a local economy in Harpers Ferry.

However, Confederate troops did not stay long in 1861 for the newly reestablished economy to continue flourishing with services for the soldiers. In the winter of 1861 and early months of 1862, both armies had vacated Harpers Ferry and left it without a viable economy. As a result, the townspeople fled the town in droves. As Annie Marmion recorded in her postwar memoir, the town had about 20 families left, and silence reigned in the town. ${ }^{104}$ Combined with Barry's comment about the value of soldiers to the town's economy, Marmion's assertion of silence and under 100 people in the town point to the fact that regardless of the uniform of the occupying army, the presence of troops in the town allowed for townspeople to stay and to attempt to continue their livelihood. In March 1862, the federal army entered Harpers Ferry and occupied it for the first time.

The Union occupation, even with the interactions with Confederate armies that forced them to vacate the town temporarily, represented much of the occupation experience for Harpers Ferry's townspeople. In the spring of 1862, the town's economy and population were renewed by the presence of troops. Barry describes this revitalization as a product of the "great number of soldiers" and the "many strangers, who daily arrived to visit friends in the army." As the federal

\footnotetext{
${ }^{103}$ Josephus, Jr., The Annals of Harper's Ferry with Sketches of its Founder, and Many Prominent Characters Connected with its History, Anecdotes \&c... (Martinsburg, WV: The Berkeley Union, 1872), 64.

${ }^{104}$ Annie Marmion, Under Fire: An Experience in the Civil War, ed. William Vincent Marmion, Jr. (1959).
} 
army set up a base of operations and of supplies in the town, the townspeople again reestablished their economy around the military presence. The renewed occupation "threw new life into the town" with both the greater numbers of soldiers and civilians and the revival of business in Harpers Ferry, according to Barry. The economy boomed again as many townspeople renewed or established profitable businesses in "providing little luxuries for the wearied soldiers and their friends. $" 105$

While undoubtedly the townspeople who ran these businesses profited from the military presence in the town, the soldiers also benefitted from the sale of food items and the open saloons and boarding houses. The sale of these items from both male and female townspeople filled in gaps in the army's ration and provided comforts to soldiers who were passing through the town or were stationed there for longer periods of time. All three kinds of businesses could not have existed unless the military officials and soldiers perceived a military use for it. These "little luxuries" of better food, alcohol, and a clean room and bed formed a common ground between soldiers and civilians and benefitted each.

The sale of food items was perhaps the easiest way to enter into the militarized economy of Harpers Ferry. Selling food did not require ownership of a residence or shop. Therefore, more townspeople could engage in economic transactions with soldiers and benefit from their presence in the town. George Wingate, an officer in the $22^{\text {nd }}$ New York National Guard that was stationed in Harpers Ferry, complained that the soldiers' lack of coin money, due to the rise in gold, made it difficult to purchase "berries, milk, etc., which added so much to the army ration" and to pay for laundry services. Wingate claimed that the sale of the food items and washing soldiers'

${ }^{105}$ Josephus, Jr., 78. 
clothing was the "sole support of the females of the neighborhood." supplementing the army ration, the sale of food items by local townspeople also benefited soldiers who were recovering from illnesses. Wingate also recounted that the spring water in Harpers Ferry held a significant amount of lime that caused diarrhea in most of the soldiers. In order to remedy the widespread sickness, the military allowed vendors to enter the camps to sell fresh food items such as dairy products, eggs, and vegetables. ${ }^{107}$ For Wingate's regiment, the sale of these food items by local townspeople was significant enough to document it in the regimental history.

The presence of saloons and taverns in Harpers Ferry might not have merited inclusion in those post-war documentations of regiments. Saloons and taverns were a portion of the wartime economy in Harpers Ferry, however, just like they had been before the onset of war. Officers were allowed to enter in and imbibe with alcohol, so the presence of these taverns were allowed to remain within the militarized economy. James E. Taylor, a wartime correspondent, wrote about the saloons when he documented General Sheridan's Shenandoah Valley Campaign in the fall of 1864. Taylor walked a main street in the town "in quest of hard stuff" and entered a saloon "to liquidate." Once there he found himself in the presence of a general who was discussing military matters with other officers. Taylor then left the establishment and redirected himself to the "shanty restaurants lined along the vacant lots."108 Presumably, those other restaurants were also serving alcohol to passersby, military officers, and soldiers.

\footnotetext{
${ }^{106}$ George Wood Wingate, History of the Twenty-second Regiment of the National Guard of the State of New York; From its Organization to 1895 (New York: Edwin W. Dayton, 1896), 100.

107 Wingate, 73.

${ }^{108}$ James E. Taylor, With Sheridan Up the Shenandoah Valley in 1864: Leaves from a Special Artist's Sketchbook and Diary (Cleveland, OH: The Western Reserve Historical Society, 1989), 581.
} 
Perhaps most importantly, the townspeople reoriented their economy to provide housing for soldiers and officers who were stationed in Harpers Ferry long-term. Boarding houses provided a more familial setting for interactions between soldiers and citizens. The military personnel who lived within these hotels and boarding houses ranged from generals in charge of major campaigns to lowly privates assigned to desk work. The diversity of the interactions between military personnel and the townspeople allowed for the keepers of the boarding houses to survive in the shifting tides of occupation and of military engagements.

Townswomen's livelihood became increasingly centered around renting rooms to strangers who arrived in Harpers Ferry. While soldiers and officers formed the bulk of the boarders, hotels and boarding houses also accommodated those who followed the troops. During the Shenandoah Campaign in the fall of 1864, James Taylor arrived in Harpers Ferry and was immediately approached by a servant who offered to take Taylor to what he described as the best hotel in the city. The servant led Taylor to "Hotel de Stipes" on Shenandoah Street, a main street in town. In his description of Cornelia Stipes's boarding house, Taylor noted that she provided “table board and lodging, not from choice but necessity caused by her husband's business reverses owing to the War, and his inability to catch on again." 109 In this circumstance, Stipes opened her home to the travelers like Taylor and other soldiers to keep her family afloat after her husband was no longer able to financially provide for his household. The length of travelers' stays could affect the fledging businesses as well. At one point, when Taylor returned to Harpers Ferry, he noted that he had not been a profitable customer for Mrs. Stipes. ${ }^{110}$

Several generals during important campaigns stayed at boarding houses while in Harpers Ferry. In September 1862, when Colonel Dixon Miles surrendered control of the town to

\footnotetext{
${ }^{109}$ Taylor, 29-30.

${ }^{110}$ Taylor, 278.
} 
Confederate General Thomas Jackson, some of those in command of both Union and Confederate troops were boarded in these hotels or "rooms." On the day of the surrender, Elizabeth Brown, a wife of a captain in the Potomac Home Brigade, overheard a conversation between Colonel Miles and Colonel Ford. Ford stayed in "Mrs. Buckle's room" on Bolivar Heights where he and Miles discussed whether to surrender to the Confederate troops. Elizabeth Brown described herself as anxious to know the fate of her husband on the battlefield, so she slipped off her shoes and lifted up a floorboard to overhear the conversation. Later, during the military commission about the surrender, she was called as a witness. ${ }^{111}$ While her testimony did not comment on whether she and her husband were also staying in a room of Mrs. Buckle's, it is clear that Colonel Ford, who was one of the officers charged with inappropriately surrendering and therefore one of the top-ranking officials in Harpers Ferry at the time, was renting a room from a local townswoman. Indeed, when James Taylor grew tired of boarding on one of the busiest streets in Harpers Ferry in 1864, his landlady, Mrs. Stipes, directed him to a farmhouse where Mrs. Buckle was still renting rooms. ${ }^{112}$

However, it was not just Union officers who stayed in boarding houses in September 1862. Confederate generals, who briefly rested after the surrender and before continuing to Sharpsburg, Maryland, also rented rooms. Also during the military commission about the surrender, Captain Charles Goodman, who served as an assistant quartermaster in the Union army, recounted how he boarded next to Confederate General A.P. Hill. In his testimony, Goodman said that he had not been removed from his hotel room as he was sick in bed during the surrender. His room looked out over a main street in the town. The day after Miles

\footnotetext{
${ }^{111}$ Testimony of Elizabeth Brown, wife of Captain Brown, First Regiment Potomac House Brigade, in O.R., vol 19, part 1, 719-720.

112 Taylor, 253.
} 
surrendered, late in the evening, a courier rushed into his room and announced that he had a message from Jackson for General Hill. After directing him next door to Hill's room, Goodman overheard the conversation between the courier and Hill. ${ }^{113}$ In 1864, when Harpers Ferry once again became a strategic location for the Union advance into the Shenandoah Valley, General Phillip Sheridan set up his headquarters in what he called a "small and very dilapidated hotel."114

The most important relationships that local townswomen could form was not with the generals or the reporters who stayed for a short time but with the soldiers who were stationed indefinitely in Harpers Ferry. These soldiers who stayed at boarding houses to avoid the perilous conditions in the camps helped to solidify the economy of boarding houses and of the other military-oriented businesses. Charles Moulton, the member of the Provost Guard who wrote about the elopement of the young girl, was stationed in Harpers Ferry for almost two years from the summer of 1863 to May 1865. For a significant amount of that time, he boarded with one landlady. In December 1863, Moulton commented in a letter that he found it "very comfortable to have a good bed, and have a room, live in a house... and to fare in a civilized manner." $\mathrm{He}$ describes the experience of being out of the camps as now "indulging in the career of a gentlemen soldier." In addition, the other clerks working in the Provost Marshal's office as well as the captain also stayed at the same boarding house. However, the clerks like Moulton paid significantly less than the captain for the same services from the landlady. ${ }^{115}$

The relationship between Moulton and his landlady was not simply economic.

Undoubtedly the landlady did need the income she generated from boarding soldiers, but in his letters, Moulton speaks of her with affection and respect. In this relationship, the economic

\footnotetext{
113 Testimony of Captain Charles Goodman, in O.R., vol 19, part 1.

114 Phillip Sheridan, Personal Memoirs of P. H. Sheridan, vol 2 (New York: Jenkins \& McCowan, 1888$), 467$.

115 Moulton, December 20, 1863 letter, 151-152.
} 
motives supported the familiarity of soldiers to the local townswoman and mitigated the experiences of occupation for her. By showing kindness to the soldiers, this landlady received a steadier stream of business and several favors from her boarders. During Christmas 1863, Moulton described how his "kind" landlady arranged for a turkey dinner for the boarders at her expense. ${ }^{116}$ Just a month later, he asked the landlady to make some pies from dried fruit that his mother had sent him. ${ }^{117}$ His landlady also held meals for him during the busiest parts of the day when he could not get away from the provost marshal's office for dinner and allowed her boarders to pay her later if the government had not yet issued their pay. In response to these kindnesses, Moulton regularly gave her food and clothing that the provost marshal had confiscated and declared as contraband. ${ }^{118}$ After staying for over a year in the boarding house, Moulton described his experience there: "we have good comfortable quarters, a real bed with a bedtick, sheets and pillow cases, and blankets — why should we complain and nary a cause is there to either! And what is more-we don't!" ${ }^{119}$ Throughout his letters back to Massachusetts, Moulton demonstrated affection for his landlady and consistently remarked how the boarding house had made his time more pleasant in Harpers Ferry. Female townspeople and the troops forged a link between their experiences in the occupied town through the services that women provided to the military.

As women reoriented the town's economy around the needs of the occupying armies, they were not necessarily bound patriotically to the Union cause. Rather, the practicality of survival in an occupied town sometimes necessitated flexibility in perceived loyalty. In studies of other occupied towns, historians have shown the malleability of perceived loyalty around the

\footnotetext{
${ }^{116}$ Ibid.

${ }^{117}$ Moulton, January 17, 1864 letter, 165.

${ }^{118}$ Moulton, June 7, 1864 and June 21, 1864 letters, 188-191.

${ }^{119}$ Moulton, December 9, 1864 letter, 220.
} 
occupying troops. In these cases, those with opposing loyalties did not necessarily resist the military occupation. Resistance was not the default setting of citizens' reaction to occupation. In Natchez, Mississippi, women with fierce Confederate sympathies socialized with Union troops to maintain their elite status. Other cities in the border region between the North and South fluctuated between occupation by Confederate and Union armies, and the response of these shifting occupations was silence from the other side's supporters. In addition, loyalty was an ongoing process throughout the Civil War, and citizens' support for either the Union or the Confederacy could shift based on the policies of occupation. ${ }^{120}$ This trend in other occupied regions was also present in Harpers Ferry. While the townspeople did reorient their economy around the military, they remained occupied and needed to prove their loyalty to the occupying troops to remain within the town limits.

The shifting loyalties during wartime meant that services provided to soldiers did not guarantee that townspeople were not going to aid the opposing army. George Wingate recounted the interaction of an elderly woman with solders in the $22^{\text {nd }}$ New York National Guard. The old woman claimed to be a Union sympathizer, and because of her perceived loyalty, the soldiers of the $22^{\text {nd }}$ regularly bought berries from her. After a march, the uniforms of the soldiers were so dusty that they appeared grey rather than blue. The old women apparently believed that the marching Union soldiers were instead Confederate soldiers who were attacking the Union lines outside of Harpers Ferry. When they passed her, the woman praised them and called out, "Success over the Yanks!” According to Wingate, "her trade fell off" after this incident. ${ }^{121}$ In

\footnotetext{
${ }^{120}$ Cita Cook, "The Practical Ladies of Occupied Natchez," in Occupied Women: Gender, Military Occupation, and the American Civil War, ed. LeeAnn Whites and Alecia P. Long (Baton Rouge: Louisiana State University Press, 2012), 117-134. Robert McKenzie, Lincolnites and Rebels: A Divided Town in the American Civil War (New York: Oxford University Press, 2006). Judkin Browning, Shifting Loyalties: The Union Occupation of Eastern North Carolina (Chapel Hill: University of North Carolina Press, 2011).

${ }^{121}$ Wingate, 107.
} 
another incident in July 1864, when the Union occupying troops quickly departed Harpers Ferry due to the approach of Jubal Early, Moulton recorded that two citizens fired at Union soldiers. Moulton emphasized the need to root out disloyalty: "This is the time to find out these treacherous villians who play off their Union sentiments so well until their real friends are near." 122 The uncertainty of loyalty forced the question of the appropriate regulations for occupation.

Military officials adjusted to the idea that the townspeople they encountered on a daily basis, whether as food vendors, tavern keepers, or the woman washing their clothing, might not be loyal to their cause. Despite the service industries that developed around the presence of soldiers, the townspeople were required to either accept their presence or to leave the town, but internal political or ideological beliefs were not necessarily bound to the same necessity. Therefore, despite local women's economic reliance on soldiers, the military still had to enforce occupation policies and regulations on the townspeople because of the threat of divided loyalties.

The military officials running the supervision and surveillance of the town were largely provost marshals. As William Blair demonstrates in his study of treason during the Civil War Era, these provost marshals were part of a bewildering system of military governance that extended beyond just regulating soldiers but also occupied towns throughout the Confederacy and border regions and regulating conscription in the North. As the Union army struggled to address all the problems that arose from a large-scale war, occupation policies changed over time. The provost marshals on the ground in occupied territories drove their own policies and demonstrated severity or flexibility in response to the challenges that certain areas posed. ${ }^{123}$ In Harpers Ferry, the duty of regulating the potentially disloyal townspeople fell to the provost

\footnotetext{
${ }^{122}$ Moulton, 193-195.

${ }^{123}$ Blair, With Malice Toward Some, 100-127.
} 
marshal and his provost guard. The writings of Charles Moulton, a clerk in the provost marshal's office, are the best source for understanding the nature of occupation policies In hareprs Ferry. As he wrote home to his family in Massachusetts, he frequently discussed the policies of occupation in the town and his encounters with the female townspeople.

The policies of occupation in Harpers Ferry then fell into three main duties concerning townspeople. First, the military regulated entering, leaving, and walking around the town. Guards routinely asked for a pass that could only be obtained at the provost marshal's office by declaring an oath of allegiance to the federal government. In addition to the oath of allegiance, clerks in the office questioned every person applying for a pass about why they desired to enter the town and how long they intended to stay. The pass also contained a physical description of the holder. Charles Moulton elaborated on the process by which they obtained that physical description: in the front office, there were "fine chances afforded to see the pretty girls, gaze at their smiling countenances and ask them their ages respectively, look at the color of their eyes and hair, take their length etc., then laugh to hear them sputter and look mad because we are so 'confounded strict." $" 124$

These women's frustration with Moulton and the other clerks in the provost marshal's office might have been caused by the frequency that they were required to go into the office to obtain the pass. According to Moulton, the busy time for the clerks was on the first day of the month when all the passes expired and the townspeople came back to renew them. On those days, over a hundred people were coming into the office to receive continued permission to walk the streets of their town. ${ }^{125}$ The monthly renewal of passes then put Moulton's comments into greater perspective. Women reported to the provost marshal's office each month and witnessed

\footnotetext{
${ }^{124}$ Moulton, 139, 169

${ }^{125}$ Moulton, 165.
} 
the clerks behind the desks staring at them and remarking on their physical appearances. In this context, Moulton's attributed comment that women found the system "so confounded strict" appears to be a commentary on both the role of the clerks and the pass system. However, Moulton later described the system as part of the military necessities for defending (and occupying the town). Regardless of the inconvenience caused for both townsperson and clerk, the system prevented that "any body might pass through our lines as rebel spies and every one else, without being detected." ${ }^{\prime 26}$ By couching the language of the pass system in terms of preventing disloyalty, the provost marshal clerk considered it vital for the safety of the strategic town. In addition, while Moulton did bend the rules of military occupation when he gave contraband items to his landlady, he did not consider the pass system to be negotiable but rather a firm condition of an occupied town.

Just as the pass system served to prevent spying, the second main duty of the provost marshal also revolved around eliminating disloyal activity. While stationed in the provost marshal's office, Moulton regularly read letters sent in and out of Harpers Ferry. In one day, he read through roughly 300 letters to "check the contraband views." Clerks examined every letter that went through Harpers Ferry to ensure that military information or disloyal sentiment was not passed along. Moulton recounted how the clerks in the provost marshal's office regularly tore up letters because of disloyal sentiment. The reading of correspondence and the shredding of disloyal letters did not bother Moulton as "not much sympathy is expressed for such persons."127 Similarly to the pass system, Moulton did not feel like there was any room for negotiation in sending out disloyal sentiment in the mail. Townspeople were forced to accept the reading of the mail as part of firm occupation policy.

\footnotetext{
${ }^{126}$ Ibid.

${ }^{127}$ Moulton, 190-1.
} 
The final way that the provost marshal interacted with civilians was through the regulation of commerce and merchants. When the townspeople reoriented their town's economy to provide service industries to soldiers, they were forced to do so within the perimeters of military regulations in occupation. Businesses relied on the military's approval of their existence. Merchants dealing foodstuffs were targeted by military regulation. One officer in the $34^{\text {th }}$ Massachusetts refused any resident of Loudon County to cross the Shenandoah River and sell produce to the townspeople, who were dependent on outside supplies being brought into the town. As a result, there were "no dinners in the village, to-day." ${ }^{, 28}$ While this ban only affected the residents of Loudon County, which was considered to be part of "Mosby's Confederacy" where guerrilla warfare was common, the policy later was changed to allow for a farmer's market to get supplies to the isolated townspeople of Harpers Ferry.

Banning outsiders from entering the town to sell food was one way that the military exerted control over commerce in the town, but equally as important were the policies that regulated prices, weights and measures. The officials in town set prices and weights for certain items; if merchants disregarded these regulations, the items were liable for confiscation. In Moulton's experience enforcing these policies, butter was the most confiscated item in Harpers Ferry. In October 1863, the occupying troops confiscated half a bushel of butter because the balls did not weigh a full pound but were sold that weight's rate. ${ }^{129}$ These two types of regulationwho could sell and what products they were allowed—shows how invested the military officials were in making sure that the commerce within the town's economy was based on loyalty and honesty. After all, if a merchant lied to customers and cheated them out of three ounces of butter

\footnotetext{
${ }^{128}$ William S. Lincoln, Life with the $34^{\text {th }}$ Mass. Infantry in the War of the Rebellion (Worchester: Press of Noyes, Snow \& Company, 1879), 119.

${ }^{129}$ Moulton, 146.
} 
despite military enforcement of these policies, that merchant could not be considered to obey other regulations that were more important to securing Harpers Ferry either as a strategic location or as a supply base.

These three methods of occupation — the pass system, reading mail, and regulating commerce - represent ways that the military attempted to prevent disloyalty and reserve Union sympathies. All three methods demonstrate the military's preoccupation with the townspeople's beliefs and political views and the significance of minor acts in disrupting a larger war effort. In this context of townspeople's reliance on the military for economic survival and the occupying troops' suspicion of disloyalty among those townspeople, women found ways to align themselves with the occupying Union troops. Just as the elderly women selling berries to Union soldiers did not believe in their cause, these acts of alignment did not necessarily mean that the female townspeople's sentiments were devoted to the Union cause. However, by aligning themselves to the occupying troops, the women of Harpers Ferry could then seek to lessen the severity of the occupation of their town and negotiate on issues of lesser military concern.

Although historians need to be careful about assigning loyalty through perceived patriotic acts, ${ }^{130}$ the economic alignment only extended so far to assert dependent status on the soldiers. Indeed, due to the necessities of war and military occupation, these women needed to align themselves politically and patriotically to position themselves to negotiate occupation policies. With these patriotic acts, the women of Harpers Ferry could extend their influence beyond the economic contribution they represented to the soldiers.

\footnotetext{
${ }^{130}$ A definitive view on the women's loyalties and political stances cannot be determined from the sources available about these patriotic actions. While soldiers' memoirs and regimental histories cannot tell the internal thought processes of the women's actions, they embody the gaze of the independent male and the soldiers' perception of loyalty. Knowing these limitations of the sources, I look at these incidents as being indicative of whether the military accepted them as genuine patriotic acts and not whether the women themselves fully believed in the Union cause.
} 
The first type of patriotic act that these women showed toward occupying Union troops was to attend their dress parade. When the $34^{\text {th }}$ Massachusetts first arrived in Harpers Ferry in the summer of 1863 , the regiment held a dress parade nightly. On multiple occasions, when Moulton was attached to his unit before he was reassigned to the provost guard, he commented on the beautiful women that flocked around the parade ground. In one letter from early August, Moulton believed that "quite a number of good looking girls" had taken "quite a fancy to the gallant $34^{\text {th }}, " 131$ Almost three weeks later, Moulton again noted the presence of Harpers Ferry women at the dress parade. Moulton again emphasized the beauty of the women who were watching the soldiers. "Some of the fairest specimens of Southern beauty" attended their evening dress parades, which "seem[ed] to afford quite an attraction to them judging from the number who are constant spectators." ${ }^{\prime 32}$ The presence of these women clearly stroked Moulton's ego. In other letters from Harpers Ferry, much like the letter recounting the "most novel instance" described at the opening of the chapter, Moulton drew his distance from women that he perceived as disloyal or uncouth. When describing similar beautiful ladies in the provost marshal's office, he described their illiteracy as the reason they were unworthy of him. ${ }^{133}$ In comparison, when Moulton described the women who watched the dress parades, he instead emphasized their beauty and their seeming attraction to the occupying troops. Additionally, he does not link them to any potential disloyalty because of their place of residence.

As women attended these dress parades in the summer of 1863 , it was an effort to align themselves with the military. By watching Union soldiers march and drill in their uniforms and, although fancily, prepare themselves for armed conflict with the Confederate forces, women

\footnotetext{
${ }^{131}$ Moulton, 128.

${ }^{132}$ Moulton, 130.

${ }^{133}$ Moulton, 139.
} 
seemed to show their support for the Union cause. While their loyalty cannot be effectively determined by dress parades, Moulton linked their sympathies to Union soldiers with their presence. The women had proved themselves to Moulton in a simple way, and that approval could later mitigate the severity of occupation.

Other simple actions could win praise from the occupying Union troops as well. Moulton and the regimental history of the $34^{\text {th }}$ Massachusetts both describe a group of local women serenading the soldiers in July 1863. According to Moulton, ladies from Harpers Ferry sang the regiment "several fine songs," and in return, the regimental band treated them to "a few patriotic airs." ${ }^{134}$ The regimental history of the 34th goes into significantly more detail than Moulton in describing this interaction between troops and local women. In this account, the young women approached Regimental Headquarters, and the men quickly made seats for them out of "valises turned on end" and "seats...made out of trunks." The women then sang "patriotic songs," and the band replied with their "choicest airs." In response, the soldiers responded by cheering. In addition, an unnamed woman from Bolivar was considered to be especially interesting because she had refused to surrender the Union flag when the town was captured by Confederates. Instead, she "wrapped it round her person, and, pistol in hand, bade them 'come and take it." 135 Both accounts emphasize the patriotic songs performed by local women and the regimental band. Interestingly, the accounts differ on which group is described as patriotic. In Moulton's letter, the women simply performed "fine songs" whereas the band performed the patriotic songs. In the regimental history, the descriptions are flipped. Either way, the women of the town, and particularly the unnamed lady, had clearly distinguished themselves as loyal in the eyes of the occupying troops. In addition, the women held in esteem had placed herself in harm's

\footnotetext{
${ }^{134}$ Moulton, 123.

${ }^{135}$ Lincoln, 120.
} 
way with her attempt to save the symbol of the Union cause. This gathering occurred soon after the $34^{\text {th }}$ Massachusetts entered the occupied town.

Both the serenade of soldiers and gathering for dress parade are relatively small actions in the grand scheme of the war, but they were meaningful enough for the soldiers present to write letters and later record in the history of their regiment. Soldiers signified the importance of these actions when occupying the town. In addition, some female townspeople demonstrated their perceived loyalty in a more blatant way in July 1861 . Women presented the Union flag to the first federal occupying troops that entered the town. After hiding it during the early Confederate occupation, when the $2^{\text {nd }}$ Massachusetts arrived in town, the citizens and the soldiers held an elaborate ceremony for the presentation. In a post-war recounted speech, Annie Marlatt told the occupying soldiers:

Soldiers of the Union: Thankful that you have come here to protect our homes and our firesides, and in view of your kind and manly bearing toward us, we, the ladies of Harper's Ferry, take pleasure in presenting you this banner,--the Stars and Stripes which our forefathers, our Washington, and our kinsmen, both North and South, fought under. Take it, and may you preserve it unblemished; and may it be a beacon of protection to life, liberty, and happiness, wherever it may float! You may then rely upon the prayers, blessings, and good wishes of the ladies of Harper's Ferry. ${ }^{136}$

According to the 1860 census, Marlatt was 19 years old at the time of this speech. She had three male relatives who were employed as workers in the federal armory. ${ }^{137}$

This presentation of a regimental banner is unusual in the broader view of flag presentations during the Civil War. Historian Wayne K. Durrill wrote that flag presentations served as a social ritual to force otherwise reluctant young men to join the Confederate military. When local women presented a flag in a ceremony, they used social pressure on the men, who

\footnotetext{
${ }^{136}$ Alonzo H. Quint, The Record of the Second Massachusetts Infantry, 1861-1865 (Boston: James P. Walker, 1867), 40-41.

1371860 United States Federal Census (Provo, UT: Ancestry.com Operations, 2009).
} 
were less enthusiastic about secession and the Confederate cause. Durrill argues that these flag presentation ceremonies emphasized the three themes of manhood, faith, and community to convince the male citizens to enlist. ${ }^{138}$ However, the ladies of Harpers Ferry do not fit within this narrative of flag presentation ceremonies. First, they intentionally waited until they could present it to federal troops. In addition, this regiment was not from a region near them; instead, they presented it to a Massachusetts regiment which the male citizens of the town could not join. The local women also address the troops in a different way than they would if the regiment was locally based.

Instead, Marlatt's speech emphasized the shared connection between the federal troops and the women of Harpers Ferry. The flag was presented in part "to protect our homes and our firesides" - or the physical manifestations of the household. Marlatt also acknowledged that the troops' conduct toward them was part of the motivation in presenting the banner. In addition, she called on the soldier of the Second Massachusetts to use it as a "beacon of protection to life, liberty, and happiness." In effect, Marlatt asked if the occupying troops would protect them as dependents. Her emphasis on the household and the protective role of soldiers demonstrate that she pledged herself as dependent on the troops. Therefore, as dependents, they should be protected from harm. The flag then served as a symbol of the townswomen's dependency and alignment with occupying troops.

In response, the colonel of the Second Massachusetts declared:

We are proud, ladies of Harper's Ferry, to receive from your hands this emblem of our unbroken nationality. The presentation of our nation's color on Virginia soil, by Virginians, to a regiment of patriotic, Union-loving soldiers from Massachusetts, is significant. It is an appeal, by men and women of Virginia, to Massachusetts soldier, to protect them in their constitutional rights and privileges against the treasonable efforts of

\footnotetext{
${ }^{138}$ Wayne K. Durrill, "Ritual, Community and War: Local Flag Presentation Ceremonies and Disunity in the Early Confederacy" Journal of Social History 39, no. 4 (2006): 1105-1122.
} 
rebels, who are represented by that despicable secession-rag that dare to flaunt its accursed folds upon our nation's soil.

Ladies of Virginia, we accept this color with the responsibilities that it brings. Our fathers and your fathers fought together to establish the government which the old StarSpangled Banner represents; and, so long as life shall linger in a single Northern heart, so long we swear to uphold this flag, and accord to you the protection it is able to offer! ${ }^{139}$

With this speech, the military officer had accepted the offer of the townswomen's dependency. As the colonel spoke about the "responsibilities" and the "protection" that accompanied the Union flag, he used the rhetoric of mutual obligations in the relationship between independent men and their dependents. Thus, by accepting the flag with its responsibilities, the military officer acknowledged that these female citizens were now dependents of the Union troops.

It was then through the reorientation of the economy and these acts of perceived loyalty that women could mitigate the effects of military occupation. Women proved the worth of their continued presence in the town by their service work that catered to the soldiers, and they reassured wary soldiers that they were not perceivably disloyal. By these acts, the women asserted themselves as dependents of the occupying troops and bypassed more traditional notions of paternal and hierarchical control. If these women were more scrupulous in their adherence to the idea of dependency, they would have appealed to their fathers or husbands or to the Confederate government. Instead, the declaration of dependency on Union troops demonstrate that there was room for women to choose in Harpers Ferry. In addition, by choosing for themselves in what might be construed as a political way, the townswomen demonstrated that the notions of femininity and dependency varied in their town and held room for self-assertion in the events of the Civil War.

This assertion of dependency allowed women to mitigate the occupation of Harpers Ferry. The clearest example of this mitigation comes from the daily necessity of acquiring food.

${ }^{139}$ Quint, 40-41. 
As previously mentioned, the military regulated all commerce in the town. While smuggling and a black market for certain goods undoubtedly existed in Harpers Ferry during the war, there also needed to be a regular market to provide the townspeople with food. At one time in 1864, Union officials cut off the access to the produce of Loudon County by denying any farmers attempting to sell to the residents. In the fall of that year, however, a farmers' market had been reintroduced. As James E. Taylor described it, this market, which was held each day except Sunday, granted the farmers from Loudoun County "a privilege from necessity." Farmers, without any guarantee of their loyalty, were allowed to sell food to the residents of Harpers Ferry, "providing they guarded their tongues and attend strictly to the business in hand." A rope separated the farmers and the residents of Harpers Ferry, and the provost guard closely monitored the interactions to prevent any undue conversation or communications between the two groups or anyone from entering the town. ${ }^{140}$ This market produced through negotiation between residents and the occupying troops of Harpers Ferry. It compromised between two sets of necessities - the access to a consistent food source for the residents and the need for military surveillance and control over commerce. Through this negotiation, the idea of the military as the head of the occupied household was sustained - the military needed to provide for its dependents, who would then have allegiance to that military.

The ability to acquire food was essential for women to stay in Harpers Ferry, but that was not the only way that they negotiated with the Union occupiers. Indeed, while food and the farmers' market represents a clearer set of expectations between the two groups, local women also used their relationship with military officers to obtain access to luxuries that were more representative of the antebellum time. Women sought out amusements, like balls and music,

\footnotetext{
${ }^{140}$ Taylor, 30-31.
} 
through their connections with the occupying troops. On major holidays, the occupying troops held balls for the officers and the townspeople. In 1863, the $34^{\text {th }}$ Massachusetts held a Thanksgiving ball attended by "all the principal ladies in and about the town" and "the wives and daughters of many officers high in rank in the Army of the Union." ${ }^{141}$ Just a month later, on New Years' Eve in 1863 , the $34^{\text {th }}$ Massachusetts arranged another ball to be attended by officers and the "ladies of the neighborhood." However, because of the weather, these women retracted their previous acceptance of the invitation with regretful notes. ${ }^{142}$

These social events between local women and military officers and soldiers happened more frequently than just major holidays. In the military commission following Dixon Miles's surrender to Jackson, some questions centered on whether Miles had been intoxicated during the siege. Lieutenant Henry M. Binney defended Miles, saying that he had never seen him use any kind of alcohol. According to Binney, Miles had been tempted when visiting other regiments, and even when at a private party in July, "he refused to drink with the ladies there." ${ }^{143}$ While most other aspects of Miles's leadership and his personal habits were examined before the military commission, the fact that he had attended parties with women of Harpers Ferry did not raise the question of any potential disloyalty or treason. Instead, it was accepted as a normal aspect of occupation. In addition to Dixon Miles's social events with local women, Charles Moulton also was routinely invited to evenings of "dances, parties, private visits, etc." but chose not to attend. ${ }^{144}$

The townswomen and the occupiers of Harpers Ferry then had regular social interaction with each other beyond the economic exchanges and reporting for passes. Soldiers disregarded

\footnotetext{
${ }^{141}$ Moulton, 147.

${ }^{142}$ Lincoln, 189.

${ }^{143}$ Testimony of Lieutenant Henry M. Binney in O.R. 19, part 1, 761.

${ }^{144}$ Moulton, 225.
} 
occupation policies to provide for the townswomen. Moulton regularly ignored the policies about contraband items and gave them to his boarding house keeper. In February 1864, the Union troops captured a Confederate sutler who was selling items from a supposedly loyal merchant in nearby Charles Town. Thus, all his items were confiscated as contraband. Moulton took several balls of butter and gave them to his landlady, justifying it as "no use [for her] to buy the butter when there is such a lot handy and 'spilling' too." The rest of the items were handed over to the military for use in the hospitals of Harpers Ferry. ${ }^{145}$ Instead of leaving the valuable food item for the convalescing or wounded soldiers, Moulton thought it best useful for his landlady. While this act did benefit him because he received the food cooked with butter, it benefited his landlady much more to reduce her food expense for her boarding house. While the military strictly regulated commerce in Harpers Ferry, Moulton favored the fictive household he had created with his landlady where some of the underground or illicit commerce, which might have been considered disloyal, independent, or dangerous to the social order of occupied Harpers Ferry, could be excused on the basis of her loyalty and dependence and the domestic affections between the two.

Increasingly the soldiers became more and more familiar with local townspeople and families living within Harpers Ferry. The occupying troops acted sometimes as a part of the family. They visited local families and joined them for meals. On September 14, 1862, just prior to the Battle of Harpers Ferry, Frederick Fout "stopped to get a little lunch at the home of a German family, and tied my horse to the hitching rail outside." ${ }^{\text {416 }}$ In late 1863 and early 1864, Phillip Koempel gained a close connection with a German family who moved on Bolivar Heights

\footnotetext{
${ }^{145}$ Moulton, 172.

${ }^{146}$ Frederick W. Fout, The Dark Days of the Civil War, 1861 to 1865: The West Virginia Campaign of 1861, the Antietam and Harper's Ferry Campaign of 1862, the East Tennessee Campaign of 1863, the Atlanta Campaign of 1864 (first printed by F. A. Wagenfuehr in 1904), 111.
} 
and described as "staunch Union people." He and eleven other German soldiers "very often...had a good dinner at the Wills' house, enjoying home-made cooking, home-made cider, and for this we always paid." He described the place as a second home where they often “enjoy[ed] a dance and other sociable events." Indeed, for the daughter's birthday, the soldiers were invited "to supper and a dance" where they "had a glorious time, dancing, singing, drinking 'home-made cider' the best the country could afford under the circumstances." ${ }^{.147}$ It is impossible to know if the German family described as living on Bolivar Heights is the same between the two accounts. However, it is clear that Koempel and other soldiers in his company enjoyed the company of the Wills family.

Their shared German ancestry tied the two groups of soldiers and citizens together, and at times, Koempel's memoir appears to indicate a closer link than friendship. He described a tree outside the Wills' house where the "fair daughter Kathie" offered his horse a drink and conversed with Koempel until he had to rejoin the troops. Koempel alluded further by writing that he "never prevented my horse from making that tree a 'half way' station." ${ }^{148}$ Koempel and the Wills family treated each other like family with pleasant visits and regular interactions, and Koempel himself might have wanted to solidify that familial relationship. He did not show any animosity toward the Southern family and instead sought them out as a source of comfort.

While Koempel did not marry Kathie Wills, other soldiers did legally become the heads of household with marriages to townswomen. These soldiers did explicitly join the Harpers Ferry families and solidify the dependency on local townswomen. In February of 1864, the convalescents in the hospital from the $34^{\text {th }}$ Massachusetts were ordered to leave Harpers Ferry.

\footnotetext{
${ }^{147}$ Phillip Koempel, Phil Koempel's Diary, 1861-1865 (privately published, 1923), 53.

${ }^{148}$ Ibid.
} 
Two soldiers were forced to leave behind wives. A soldier named Howard ${ }^{149}$ had married a girl from Harpers Ferry, and another named Angell ${ }^{150}$ had to "defer the consummation of his marriage, with one of the Bolivar damsels. ${ }^{\text {} 151}$ In another incident, a sergeant in the $34^{\text {th }}$ married a woman of Harpers Ferry in January 1864 . They were married by a chaplain of the $93^{\text {rd }}$ Pennsylvania Volunteers. ${ }^{152}$ After an elopement between a woman and a soldier in March 1865, Charles Moulton remarked that as "these sorts of marriages have become quite a general thing in this part of the country of late," he "presume[d] that I might get married any day I chose to in this manner." After over a year serving in the provost marshal office, he had met "quite a number of fair young damsels" and one in particular who "is a fine young lady...about 19 years of age and a perfect 'charmer' in every respect.", 153

Marriage was the most visible way in which women in Harpers Ferry chose the person to whom they were dependent. These weddings between soldiers and young women were the final conclusion of the military as the head of household and occupied townspeople as dependents. Rather than resisting military authority completely, the women of Harpers Ferry reoriented their town's economy around the presence of the military to cope with the loss of a vital factory. In doing so, these women opened the door for negotiations between townspeople and the military to mitigate the harsh effects of occupation. These negotiations were the result of a new form of traditional power: women's roles in choosing to whom they would become dependent.

The concluding marriages that accompanied the end of military occupation in Harpers Ferry is perhaps best represented by a marriage between Julia Hartshorne of Bolivar and a Union

\footnotetext{
${ }^{149}$ William Howard served as a private in Company I. His rank is not mentioned in Lincoln's source but found using the National Park Service's Soldiers and Sailors database, which confirms a soldier named Howard in Company I.

${ }^{150}$ This refers to Private George H. Angell in Company E of the $34^{\text {th }}$ Massachusetts. This information was confirmed by using the NPS's Soldiers and Sailors database.

${ }^{151}$ Lincoln, 207.

${ }^{152}$ Moulton, 166.

${ }^{153}$ Moulton, 230.
} 
solider on March 4, 1865. As it was not legal to marry a couple in Virginia, the chaplain married the couple in the center of the Potomac bridge between Virginia and Maryland. ${ }^{154}$ Harpers Ferry had lain in a continual battleground and on the border of the North and the South since April 18, 1861. This wedding conducted on the literal border between states and between countries demonstrates how Southern women living in Harpers Ferry used dependence to solidify their own status.

${ }^{154}$ Ibid. 


\section{Conclusion}

In the late 1890 s and early 1900 s, Jennie Chambers faced a personal financial crisis. Her father Edmund Chambers, who served in the militia during John Brown's raid in 1859, attempted to stand in the armory gates to protect the equipment in April 1861, and was an avowed Unionist throughout the war, had died. Chambers, who had never married, took care of her mother, but soon they could no longer support themselves. In 1899, her mother, Mary Chambers, wrote several letters to the federal government requesting that Jennie be granted a federal pension. These letters claimed that Jennie had saved the lives of two Union soldiers by alerting them about the presence of Confederate troops nearby in October 1861. She had allegedly put herself in great personal danger by signaling to the troops. Mary Chambers had the letter witnessed by a

Josephine V. Stewart to verify its story. ${ }^{155}$ According to Mary, this selfless, patriotic act deserved a pension almost forty years later.

However, the time of occupied dependency had ended. Chambers did not receive the pension, and instead she turned to writing to support herself and her mother. Around the same time, Chambers published her account of October 16-18, 1859 entitled "What A School-Girl Saw of John Brown's Raid" in Harper's Monthly. She attempted to rehabilitate her father's image. Despite being listed as the owner of several slaves in the 1860 slave schedule, Chambers described him as an "antislavery man." The local militia had been orderly. No mention was given about the deaths of Dangerfield Newby, William Thompson, William Lehman, or Jeremiah Anderson. Instead, the townspeople had fought back against the odds and forced the bandits back into the engine-house and would have finished the raid, had the marines not shown up. ${ }^{156}$ Chambers's published account took liberties inevitable after forty years and represents the

\footnotetext{
${ }^{155}$ Mary W. Chambers, letter, January 31, 1899.

${ }^{156}$ Jennie Chambers, “What a School-Girl Saw of John Brown's Raid,” Harper's Monthly (1902).
} 
growing mythology of the Lost Cause in this era. The greater significance to the publication was that this revision of her family's history mattered to Chambers economically. She needed the money to support her remaining family, and the solution was to write what people wanted to read. The economic downturn of Harpers Ferry warranted Chambers's rewrite of history.

After the end of the war and the withdrawal of troops, the reorientation of the town's economy and the occupied dependency of the townspeople did not last. After all, without either the wages of armorers or soldiers fueling the economy, the businesses run by women could not survive. When the garrison of federal troops closed and soldiers mustered out of the service, the town was left with yet another economic void to fill. This void was briefly filled by a paper mill on Virginius Island just outside of Harpers Ferry, but that too did not last for a significant amount of time. In 1870, a major flood decimated the rebuilt industries of the town. That flood, one of the highest in Harpers Ferry's history, killed the pursuit of water-powered manufacturing in the town. ${ }^{157}$

The dependencies that had been chosen by local women during the Cold War could not last into the Reconstruction era. The crucible of the war had brought masculinity, femininity, and antebellum gender roles to the brink and forced them to adapt to novel circumstances. Without the stability of a singular manufacturing industry around which to order the town, men lost their sense of independence and, therefore, masculinity. Because of a feminized male population, women gained more authority over whom they pledged their dependency to. Both the feminized men and the occupied dependencies of the local women reordered the very idea of a southern household. During the war, men's loss of control over their dependents and women's newfound choice revealed the truth about seemingly stable manufacturing households of the antebellum

\footnotetext{
${ }^{157}$ Barry, 151-157.
} 
period. A crisis proved that the foundations of the household had always been shaky. The social constructs of gender crumbled and were rebuilt in Harpers Ferry. The Civil War demonstrates vividly the concept of changeable gender roles.

The Civil War was a crisis for southern households, but that which is formed during a crisis does not necessarily retain that form permanently. As soldiers left, the antebellum notions of gender had not given way to an entirely new, proto-feminist version of the household. Instead, these occupied dependencies proved to be a temporary solution to the problems forged by war. As quickly as households crumbled and were rebuilt in a different image, the end of hostilities caused another shift in the structure of households.

In 1870, the number of female-headed households was roughly the same percentage in the population as before the war. In fact, the various occupations of women were less diverse in 1870 than in 1860 . In part, these more homogenous occupations might be caused by a more rigid enumerating system in the 1870 census. Census workers were instructed by the federal government to place people into clearer categories. As a result, many women, who represented the head of their households, are listed as only "keeping house" without any other viable form of income visible. ${ }^{158}$ Still, even with the discrepancies and undervisibility of women's occupation, the female-headed households had not held in the five years since the end of the war. Instead, the household structures of Harpers Ferry looked rather similar, as though the crisis in household had not occurred in the ten years between the two censuses.

One particular detail about the 1870 census shows the transformative nature of the Civil War. In 1870, Harpers Ferry had many more black households than in 1860. The process of emancipation had allowed an American African version of the household to flourish in a way

${ }^{158}$ See 1870 Census, Bolivar Township, Jefferson County, West Virginia. 
that they had been unable to before. Joseph Barry, in his introduction to The Strange Story of Harpers Ferry, cited this demographic information when he discussed how Harpers Ferry had changed from the founding of the ferry across the Potomac River. ${ }^{159}$ The presence of freed black families represents a major change in the household and in the town.

Other than the change in racial demographics, though, the households do not appear to have been fundamentally altered by the instability of the Civil War. Jennie Chambers was forced to pursue a writing career after her petition for a federal pension was denied. Only a few of the claims submitted to the Southern Claims Commission were granted. One that was approved was that from Cornelia Stipes's daughter. Stipes had served the reporter, James Taylor, and military officials in her boardinghouse. After the end of the war, Anna Stipes submitted a claim of damage by federal troops. However, Stipes did not receive the full amount that she alleged. She received $\$ 109$ from the $\$ 162$ petitioned. ${ }^{160}$ Others were denied because of dubious loyalty that could not be verified. By the era of the Southern Claims Commission, the time of household networks between soldiers and local women and of lax regulations for the "loyal" was over. The government did not feel the same obligation to help those women after the war.

If the shift in household structures did not endure past the war and if gender relations reorganized yet again, a legitimate question of relevancy arises. Does this shift matter, or was the reorganization simply a blip that was quickly corrected by the end of the war? Even though the feminization of men and the choice of dependency for women was short-lived, this reorganization demonstrates the fluidity of gender. Throughout the antebellum period, gender appeared stable or even fixed. Certainly, the men and women living in the early nineteenth

\footnotetext{
${ }^{159}$ Barry, 5.

${ }^{160}$ Southern Claims Commission, Anna Stipes, microfilm reel 200-201, 205, NARA, kept at Harpers Ferry National Historical Park.
} 
century believed that the set gender roles and perceived gendered traits were natural and ordained by God. However, a long-lasting, stable system falling to pieces with various crises contradicts the notion of naturalness. The collapse of antebellum gender roles demonstrates that the people of Harpers Ferry approached the Civil War through the perspective of surviving occupation in whatever ways possible, even if that meant restructuring that which they perceived to be natural. 


\section{BIBLIOGRAPHY}

\section{Articles and Chapters}

Boydston, Jeanne. "Gender as a Question of Historical Analysis." Gender \& History 20, no. 3 (2008): 558-583.

Cook, Cita. "The Practical Ladies of Occupied Natchez.” In Occupied Women: Gender, Military Occupation, and the American Civil War, edited by LeeAnn Whites and Alecia P. Long, 117-134. Baton Rouge: Louisiana State University Press, 2012.

Durrill, Wayne K. "Ritual, Community and War: Local Flag Presentation Ceremonies and Disunity in the Early Confederacy." Journal of Social History 39, no. 4 (2006): 11051122.

Eby, Cecil B. "The Last Hours of the John Brown Raid: The Narrative of David H. Strother." The Virginia Magazine of History and Biography 73, no. 2 (1965): 169-177.

Webster, Donald B., Jr. "The Last Days of Harpers Ferry Armory.” Civil War History 5, no. 1 (1959): 30-44.

\section{Books}

Ash, Stephen V. When the Yankees Came: Conflict and Chaos in the Occupied South, 18611865. Chapel Hill: University of North Carolina Press, 1995.

Blair, William A. With Malice Toward Some: Treason and Loyalty in the Civil War Era. Chapel Hill: University of North Carolian Press, 2014.

Boydston, Jeanne. Home and Work: Housework, Wages, and the Ideology of Labor in the Early Republic. New York: Oxford University Press, 1994.

Browning, Judkin. Shifting Loyalties: The Union Occupation of Eastern North Carolina. Chapel Hill: University of North Carolian Press, 2011.

Carton, Evan. Patriotic Treason: John Brown and the Soul of America. New York: Free Press, 2006.

Creighton, Margaret. The Colors of Courage: Gettysburg's Forgotten History: Immigrants, Woman and African Americans in the Civil War's Defining Battle. New York: Basic Books, 2005.

Duncan, Richard R. Beleaguered Winchester: A Virginia Community at War, 1861-1865. Baron Rouge: Louisiana State University Press, 2007. 
Edwards, Laura F. Scarlett Doesn't Live Here Anymore: Southern Women in the Civil War Era. Urbana, IL: University of Illinois Press, 2000.

Faust, Drew Gilpin. Mothers of Invention: Women of the Slaveholding South in the American Civil War. Chapel Hill: University of North Carolina Press, 1996.

Finkelman, Paul. His Soul Goes Marching On: Responses to John Brown and the Harpers Ferry Raid. Charlottesville, VA: University Press of Virginia, 1995.

Fox-Genovese, Elizabeth. Within the Plantation Household: Black and White Women of the Old South. Chapel Hill: University of North Carolina Press, 1988.

Frye, Dennis. Harpers Ferry Under Fire: A Border Town in the American Civil War. Virginia Beach, VA: Donning Co. Publishers, 2011.

Gillespie, Michele. Free Labor in an Unfree World: White Artisans in Slaveholding George, 1789-1860. Athens, GA: University of Georgia Press, 2000.

Glymph, Thavolia. Out of the House of Bondage: The Transformation of the Plantation Household. New York: Cambridge University Press, 2008.

Hearn, Charles. Six Years of Hell: Harpers Ferry during the Civil War. Baton Rouge: Louisiana State University Press, 1996.

Holsworth, Terry W. Civil War Winchester. Charleston, S.C.: History Press, 2011.

Horowitz, Tony. Midnight Rising: John Brown and the Raid that Sparked the Civil War. New York: Henry Holt and Co., 2011.

Johnson, Walter. Soul by Soul: Life Inside the Antebellum Slave Market. Cambridge, MA: Harvard University Press, 1999.

McCurry, Stephanie. Confederate Reckoning: Power and Politics in the Civil War South. Cambridge, MA: Harvard University Press, 2010.

----. Masters of Small Worlds: Yeoman Households, Gender Relations, and the Political Culture of the Antebellum South Carolina Low Country. New York: Oxford University Press, 1995.

McKenzie, Robert. Lincolnites and Rebels: A Divided Town in the American Civil War. New York: Oxford University Press, 2006.

Oates, Stephen B. To Purge this Land with Blood: A Biography of John Brown. Amhearst, MA: University of Massachusetts Press, 1970.

Quarles, Benjamin. Allies for Freedom: Blacks and John Brown. New York: Oxford University 
Press, 1974.

Reynolds, David S. John Brown, Abolitionist: The Man Who Killed Slavery, Sparked the Civil War, and Seeded Civil Rights. New York: Alfred A. Knopf, 2005.

Rockman, Seth. Scraping By: Wage Labor, Slavery, and Survival in Early Baltimore. Baltimore, The Johns Hopkins University Press, 2009.

Roediger, David R. The Wages of Whiteness: Race and the Making of the American Working Class. London: Verso, 1991.

Smith, Merritt Roe. Harpers Ferry Armory and the New Technology: The Challenge of Change. Ithaca, NY: Cornell University Press, 1977.

Stauffer, John and Zoe Trodd. The Tribunal: responses to John Brown and the Harpers Ferry Raid. Cambridge, MA: Belknap Press of Harvard University Press, 2012.

Sutherland, Daniel E. Seasons of War: The Ordeal of a Confederate Community, 1861-1865. Baton Rouge: Louisiana State University Press, 1998.

Villard, Oswald Garrison. John Brown, 1800-1859: A Biography Fifty Years After. Gloucestter, MA: P. Smith, 1966.

Wellman, Manly Wade. Harpers Ferry, Prize of War. Charlotte, NC: McNally of Charlotte, 1960.

Whites, LeAnn. Gender Matters: Civil War, Reconstruction, and the Making of the New South. New York: Palgrave MacMillian, 2005.

Whites, LeAnn and Alecia P. Long, ed. Occupied Women: Gender, Military Occupation, and the American Civil War. Baton Rouge: Louisiana State University Press, 2012.

\section{Published Primary Sources}

Barry, Joseph. The Strange Story of Harpers Ferry with Legends of the Surrounding Countryside. Harpers Ferry, WV: Women's Club of Harpers Ferry District, 1959.

Bureau of the Census, Eighth Census on the United States, 1860. Washington, D.C.: National Archives and Records Administration, 1860. Accessed through Ancestry.com. Provo, UT: Ancestry.com Operations, Inc., 2010.

--. Ninth Census on the United States, 1870. Washington, D.C.: National Archives and Records Administration, 1870. Accessed through Ancestry.com. Provo, UT: Ancestry.com Operations, Inc, 2010.

Calender of Virginia State Papers and Other Manuscripts from January 1, 1836 to April 15, 
1869; Preserved in the Capitol at Richmond. Richmond (1893).

Chambers, Jennie. "What A School-Girl Saw of John Brown's Raid.” Harper's Monthly (1902).

Fout, Frederick. The Dark Days of the Civil War, 1861 to 1865: The West Virginia Campaign of 1861, the Antietam and Harper's Ferry Campaign of 1862, the East Tennessee Campaign of 1863, the Atlanta Campaign of 1864. F. A. Wagenfuehr, 1904.

Jefferson, Thomas. Notes on the State of Virginia With an Appendix. $8^{\text {th }}$ ed. Boston, 1801.

Josephus, Jr. The Annals of Harper's Ferry with Sketches of its Founder, and Many Prominent Characters Connected with its History, Anecdotes \&c... Martinsburg, WV: The Berkeley Union, 1872.

Koempel, Phillip. Phil Koempel's Diary, 1861-1865. Privately published, 1923.

Lincoln, William S. Life with the Thirty-Fourth Mass. Infantry in the War of the Rebellion. Worchester: Press of Noyes, Snow \& Company, 1879.

Marmion, Annie. Under Fire: An Experience in the Civil War. Edited by William Vincent Marmion, Jr. (1959).

Moulton, Charles H. Fort Lyon to Harper's Ferry: On the Border of North and South with "Rambling Jour": The Civil War Letters and Newspaper Dispatches of Charles H. Moulton (34 ${ }^{\text {th }}$ Mass. Vol. Inf.). Edited by Lee C. Drickamer and Karen D. Drickamer. Shippensburg, PA: White Mane Publishing Co., Inc., 1987.

Quint, Alonzo. The Record of the Second Massachusetts Infantry, 1861-1865. Boston: James P. Walker, 1867.

Reid, Whitelaw. Ohio in the War, Her Statesmen, Generals, and Soldiers: Volume II: The History of Her Regiments and Other Military Organizations. 1867. Reprint, Cincinnati: The Robert Clarke Company, 1895.

Sheridan, Philip. Personal Memoirs of P. H. Sheridan. Vol. 2. New York: Jenkins \& McCowan, 1888.

Strother, David Hunter and Cecil D. Eby. A Virginia Yankee in the Civil War: The Diaries of David Hunter Strother. Chapel Hill: University of North Carolina Press, 1998.

Taylor, James E. With Sheridan Up the Shenandoah Valley in 1864: Leaves from a Special Artist's Sketchbook and Diary. Cleveland, OH: The Western Reserve Historical Society, 1989.

United States, Robert N. Scott, H. M. Lazelle, George B. Davis, Leslie J. Perry, Joseph W. 
Kirkley, Fred C. Ainsworth, John S. Moodey, and Calvin D. Cowles. The War of the Rebellion: A Compilation of the Official Records of the Union and Confederate Armies. Washington: Government Printing Office, 1880.

Wingate, George Wood. History of the Twenty-second Regiment of the National Guard of the State of New York: From its Organization to 1895. New York: Edwin W. Dayton, 1896.

Zittle, John and H. Minnie Zittle. The Correct History of the John Brown Invasion at Harper's Ferry, West Va., Oct. 17, 1859: Compiled by the late CAPT. JOHN H. ZITTLE, of Shepherdstown, W. Va., Who Was an Eye-Witness to Many of the Occurrences, and Edited and Published by His Widow. Hagerstown, MD: Mall Publishing Company, 1906. Microfilm.

\section{Unpublished Primary Sources}

Anne Madison Willis Ambler diary, Jefferson County Museum.

Claim of the Estate of Frederick Roeder for Resitutuion from the U.S. Government, September 5, 1902. National Archives and Records Administration.

David Hunter Strother Papers, A\&M No: 2894, West Virginia Regional History Center. Microfilm.

James Lawrence Hooff, The Journals of James Lawrence Hooff, Charlestown, Virginia, now Charles Town, West Virginia, October 7, 1859-June 1, 1864. Jefferson County Museum, West Virginia.

Jennie Chambers Papers, 1838-1936. David M. Rubenstein Rare Book \& Manuscript Library, Duke University.

Southern Claims Commission, National Archives and Records Administration. Microfilm, accessed at Harpers Ferry National Historical Park.

Writer's Program in West Virginia. Records. A\&M No.: 454, Series 4: Harpers Ferry, Box 9293. West Virginia Regional History Center. 